Chapman University

Chapman University Digital Commons

War and Society (MA) Theses

Dissertations and Theses

Winter 1-2021

\title{
Fighting Tigers with a Stick: An Evaluation of U.S. Army Recruitment, Training, and Their Combat Outcomes in the Korean War
}

Jonathan Banks

Chapman University, jbanks@chapman.edu

Follow this and additional works at: https://digitalcommons.chapman.edu/war_and_society_theses

Part of the Military History Commons

\section{Recommended Citation}

Banks, Jonathan. "Fighting Tigers with a Stick: An Evaluation of U.S. Army Recruitment, Training, and Their Combat Outcomes in the Korean War." Master's thesis, Chapman University, 2021. https://doi.org/

$10.36837 /$ chapman.000215

This Thesis is brought to you for free and open access by the Dissertations and Theses at Chapman University Digital Commons. It has been accepted for inclusion in War and Society (MA) Theses by an authorized administrator of Chapman University Digital Commons. For more information, please contact laughtin@chapman.edu. 
Fighting Tigers with a Stick: An Evaluation of U.S. Army

Recruitment, Training, and Their Combat Outcomes in the Korean War

\author{
A Thesis by \\ Jonathan M. Banks \\ Chapman University \\ Orange, CA \\ Wilkinson College of Arts, Humanities, and Social Sciences \\ Submitted in partial fulfillment of the requirements for the degree of \\ Master of Arts in War and Society \\ January 2021
}

Committee in charge:

Kyle Longley, Ph.D., Chair

Mateo Jarquin, Ph.D.

Gregory Daddis, Ph.D. 
The thesis of Jonathan M. Banks is approved.
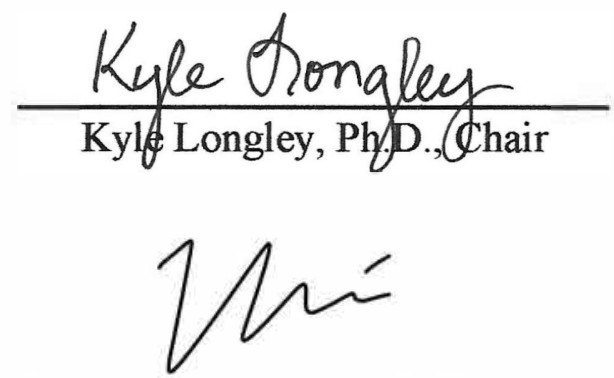

Mateo Jarquin, Ph.D.

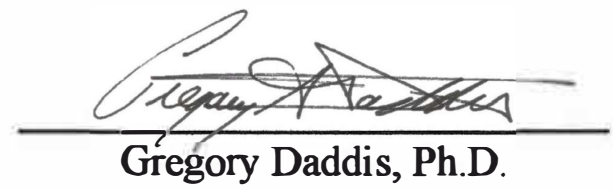

December 2020 


\title{
Fighting Tigers with a Stick: An Evaluation of U.S. Army Recruitment, Training, and Their Combat Outcomes in the Korean War
}

\author{
by Jonathan M. Banks
}

This thesis is a work of the United States government and is not subject to copyright laws within the US.

The views expressed in this thesis are those of the author and do not reflect the official policy or position of the United States Air Force, Department of Defense, or the U.S. Government 


\section{ACKNOWLEDGEMENTS}

As with all academic research, this project would not have been possible without the aid and assistance of a number of individuals. In particular, I owe great gratitude to those on the thesis committee, Drs. Kyle Longley, Gregory Daddis, and Mateo Jarquin, who demonstrated extreme patience and diligence in helping me refine my work. Additionally, my colleagues Robert Kent and Kolby Reinke served as an eager sounding board for my ideas. I also thank the staff at the U.S. Army Heritage and Education Center and Chapman University’s Center for American War Letters, without whose hard work this essay would have been greatly diminished. I owe special thanks to Dr. Douglas Kennedy, whose class at the Air Force Academy provided the initial inspiration for this project and who provided early guidance on where to begin. Special thanks also to Colonel Meg Martin whose aid and encouragement were instrumental in getting me this far. Finally, I owe very special thanks to Mr. Jerry Spangler who graciously agreed to share his story with me for inclusion in this research. Having received so much assistance in completing this project, any remaining errors or mistakes are undoubtedly my own. 


\begin{abstract}
Fighting Tigers with a Stick: An Evaluation of U.S. Army Recruitment, Training, and Their Combat Outcomes in the Korean War by Jonathan M. Banks
\end{abstract}

After the Korean War, most people regarded the performance of the U.S Army in that conflict as largely checkered. It had not once, but twice retreated disgracefully, losing to theoretically inferior third world armies. Its soldiers often performed poorly, not just in battle, but also prison camps. Many scholars, military commentators, and journalists have since tried to dissect the failures of the U.S. Army in Korea. Some have examined whether or not American GIs received proper combat training before and during the war.

Indeed, problems existed with American infantry training before and during the early phases of the Korean War. Recruitment standards slipped while leaders reduced the length of basic training. Unit level training also suffered from personnel turnover as well as a lack of training areas, equipment, and focus from leadership. Training largely became inconsistent and unrealistic as the military slipped into a peacetime mentality. As a result, the average American infantryman deploying to Korea in 1950 lacked training and education in how to fight a ground war.

Thus, the U.S Army's infantry training system prior to Korean War deservedly warranted criticism and reform. However, it was not the only factor in the Army's defeats. Instead, it reflected a larger, underlying issue. The ambivalent attitude of American civil and military society regarding ground warfare shaped the outcome of Korean War. This outlook not only created conditions leading to poor training for infantrymen, but other issues like a lack of equipment and manpower, poor leadership, and weak national morale that adversely affected the soldier's performance on the battlefields and prison camps of Korea. 


\section{TABLE OF CONTENTS}

$\underline{\text { Page }}$

ACKNOWLEDGEMENTS .......................................................................................... IV

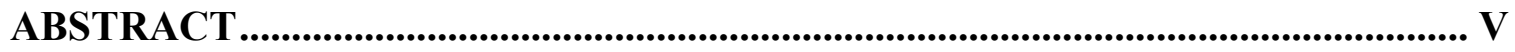

LIST OF ABBREVIATIONS …....................................................................... VII

1 INTRODUCTION............................................................................................................. 1

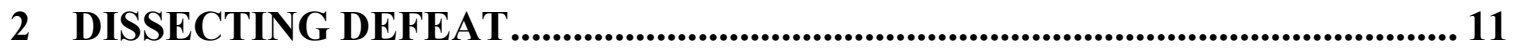

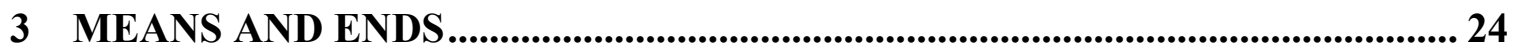

4 MUD AND BLOOD

5 CONCLUSION: AN UN-AMERICAN WAY OF WAR? .................................... 82

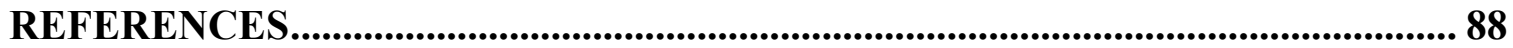




\section{LIST OF ABBREVIATIONS}

$\underline{\text { Abbreviation Meaning }}$

$\begin{array}{cl}\text { FEAF } & \text { Far East Air Forces } \\ \text { FECOM } & \text { Far East Command } \\ \text { FTX } & \text { Field Training Exercise } \\ \text { HEAT } & \text { High Explosive Anti-Tank } \\ \text { KMAG } & \text { Korean Military Advisory Group } \\ \text { KPA } & \text { Korean People's Army } \\ \text { OCS } & \text { Officer Candidate School } \\ \text { PVA } & \text { People's Volunteer Army } \\ \text { ROK } & \text { Republic of Korea } \\ \text { ROTC } & \text { Reserve Officer Training Corps } \\ \text { SCAP } & \text { Supreme Commander Allied Powers } \\ \text { SSS } & \text { Selective Service System } \\ \text { UMT } & \text { Universal Military Training } \\ \text { UNC } & \text { United Nations Command }\end{array}$




\section{Introduction}

Rob Roy was about to die. Mere hours before, the nineteen-year-old American felt safe and secure as member of the U.S. military, the most powerful force on earth. Sitting atop a small ridge overlooking a road and train tracks, Roy and his fellow soldiers were confident and cocksure. True, they were on the front lines of a war. But it was a war between two small, barely decolonized nations in the backwaters of Asia. To them, they were the big leagues as members of Task Force Smith (named after their commander, LTC Charles "Brad" Smith) and needed only to show themselves on the battlefield to cow the enemy. The aggressors soon would have no choice but to sue for peace. This was no war, just a minor police action in a remote corner of the world called Korea. Roy and his friends were unafraid. ${ }^{1}$

By mid-afternoon on 5 July 1950, however, Roy, ran for his life through the fetid rice paddies, deathly afraid. Horrified, he had watched that morning as the North Koreans charged American positions not with farmers' pitchforks, but Soviet tanks. Of course, Roy had fought back, firing round after round from his $75 \mathrm{~mm}$ recoilless rifle that all bounced harmlessly off the tanks, highlighting the lack of effective ammunition. When the blast from an enemy cannon knocked Roy and his squad from their gun, they abandoned the useless weapon. An officer told Roy to return to it, but he told the officer to do it himself.

The first wave of tanks eventually passed. ${ }^{2}$ Later, when more tanks arrived, backed by thousands of infantrymen, Roy and a squad-mate decided they were done. They sat under their poncho and had a smoke. "What the hell are you doing" an officer asked? "We're having a

\footnotetext{
${ }^{1}$ Rudy Tomedi, ed., No Bugles, No Drums: An Oral History of the Korean War (New York, NY: John Wiley and Sons, 1993), 2.

${ }^{2}$ Tomedi, 5.
} 
smoke" replied Roy. "You're about to die" the officer corrected him. "Yeah," agreed Roy, "we're having our last smoke."3

Soon after, they received orders to withdraw. Roy needed little encouragement. As the North Koreans sprayed the area with bullets, Roy and the others in Task Force Smith ran, all desperately seeking safety. Soon, Roy found himself alone, his squad captured after they turned right when Roy went left. Alone, and armed now with only a .45 caliber pistol, he was lucky and ultimately found the remnants of a friendly infantry company headed south. ${ }^{4}$ Along the way, they likely pondered their plight. They were soldiers of the greatest fighting force on the planet, up against a ragtag bunch of peasants. Yet now they stumbled back in disorder, utterly defeated. What explained their unpreparedness? What had gone so wrong with the American soldier?

Such bewilderment was understandable. A mere five years prior, the U.S Army emerged victorious from the Second World War, larger and more powerful than ever. Yet the Army of 1945 differed dramatically from forces headed to South Korea in 1950 with Roy in tow. After Japan's surrender, home front priorities and a desire to return to normal life by conscripts, resulted in a hasty and disorganized demobilization. ${ }^{5}$ As a result, the new realities of conscription, overseas garrisons, and nuclear weapons in the emerging Cold War, forced military leaders to rethink how to administer and utilize the Army. The resulting policy decisions and reforms, designed to attract and keep the manpower levels needed for overseas occupations, proved controversial, especially after U.S involvement in Korea began. ${ }^{6}$ Despite massive changes, however, many considered a new ground war as a remote possibility because of air-

\footnotetext{
${ }^{3}$ Tomedi, 6.

${ }^{4}$ Tomedi, 6-8.

${ }^{5}$ Susan Carruthers, The Good Occupation American Soldiers and the Hazards of Peace (Cambridge, MA: Harvard University Press, 2016), 194-99.

${ }^{6}$ Brian Linn, Elvis's Army: Cold War GIs and the Atomic Battlefield (Cambridge, MA: Harvard University Press, 2016), 33-35.
} 
droppable nuclear weapons. ${ }^{7}$ As a result, the early Korean debacle proved a surprising trauma for the nation and for the Army.

Indeed, debacle best describes the first engagements of the U.S Army on Korean soil. After 25 July 1950 when the Communist Korean People's Army (KPA) stormed across the $38^{\text {th }}$ parallel into the U.S backed Republic of Korea (ROK), President Harry Truman barely hesitated in sending warplanes to assist and quickly secured a U.N mandate to send ground troops. ${ }^{8}$ It required expediency, for the ROK army lacked training and equipment to repel the invasion. In contrast, the KPA was large and well equipped with 150 T-34-85 medium tanks, courtesy of the Soviet Union. ${ }^{9}$ As a result, the ROK army retreated, but U.S. leaders hoped U.S troops would steady the reeling ROKs and deter the KPA.

However, Task Force Smith was as understrength, under equipped, and underprepared as their South Korean counterparts. Almost immediately, American GIs joined the retreat as the KPA repeatedly encircled and smashed successive units hastily rushed to the front. Finally, the influx of fresh American soldiers and equipment coincided with an overextension of the KPA and allowed the Americans and ROKs to make a stand in the corner of the Korean peninsula around the port of Pusan. ${ }^{10}$

From the stabilized Pusan front, U.S. and U.N. commander, General Douglas MacArthur, launched a daring amphibious assault at Inchon on 10 September which triggered a collapse of the exhausted KPA. U.N. forces rapidly retook territory and drove the KPA back into North Korea. Some U.S commanders predicted their troops would celebrate Christmas at home.

\footnotetext{
${ }^{7}$ Linn, 10.

8 T.R. Fehrenbach, This Kind of War: The Classic Korean War History (Lincoln NE: Potomac Books, 2008), 52-58.

${ }^{9}$ Stanley Sandler, The Korean War: No Victors, No Vanquished (Lexington KY: University Press of Kentucky, 1999), 45.

${ }^{10}$ Bruce Cumings, The Korean War: A History (New York, NY: Modern Library, 2011), 16-18.
} 
However, arrogance and poor intelligence ensured a debacle. In late October the Chinese People's Volunteer Army (PVA) slammed into overextended U.N. lines, once more causing a chaotic retreat. Eventually, the Americans stabilized the front and retook ground, holding a frontline approximating the $38^{\text {th }}$ parallel. For two years afterward, they engaged in bloody engagements along this line while peace talks dragged on. ${ }^{11}$

During the fighting, thousands of American soldiers, airmen and marines became prisoners of war. They endured conditions that ranged between unsatisfactory and utter barbarism. Additionally, they faced a concerted effort by their captors to exploit them for propaganda. Many soldiers eventually participated, for a variety of reasons, in schemes designed to discredit the U.S. war effort with some choosing to never return home. Many died never having the choice. ${ }^{12}$ Finally, on 27 July 1953, the warring parties signed an armistice leaving the border almost exactly in its original place. The ferocious war unsatisfyingly resulted in more or less the status quo ante bellum.

Afterward, most people regarded the performance of the U.S Army in Korea as largely checkered. It had not once, but twice retreated disgracefully, losing to theoretically inferior third world armies. Its soldiers often performed poorly, not just in battle, but also prison camps. Many scholars, military commentators, and journalists have since tried to dissect the failures of the U.S. Army in Korea. Some have examined whether or not American GIs received proper combat training before and during the war. They focused on the weak link being U.S. soldiers' combat skills since the country had apparent material advantages against largely agrarian nations and the proven WWII successes of the senior American commanders.

\footnotetext{
${ }^{11}$ Cumings, 19-31.

12 William Latham, Cold Days in Hell: American POWs in Korea (College Station TX: Texas A\&M University Press, 2012), 4-5. Twenty-three Americans initially refused repatriation, with two of them quickly changing their minds and returning.
} 
Indeed, problems existed with American infantry training before and during the early phases of the Korean War. Recruitment standards slipped while leaders reduced the length of basic training. ${ }^{13}$ Unit level training also suffered from personnel turnover as well as a lack of training areas, equipment, and focus from leadership. ${ }^{14}$ Training largely became inconsistent and unrealistic as the military slipped into a peacetime mentality. ${ }^{15}$ As a result, the average American infantryman deploying to Korea in 1950 lacked training and education in how to fight a ground war.

Thus, the U.S Army's infantry training system prior to Korean War deservedly warranted criticism and reform. However, while some commentators blamed deficient training for causing the Army's failures in Korea, it was not the only factor in the defeats. Instead, it reflected a larger, underlying issue. The ambivalent attitude of American civil and military society regarding ground warfare shaped the outcome of Korean War. This outlook not only created conditions leading to poor training for infantrymen, but other issues like a lack of equipment and manpower, poor leadership, and weak national morale that adversely affected the soldier's performance on the battlefields and prison camps of Korea.

In accordance with longstanding American cultural and political attitudes towards war, U.S. leaders neglected the Army after WWII. Lured by the promise that nuclear weapons made ground war obsolete, they slashed the Army's budget in favor of the Air Force and Navy. ${ }^{16}$ Meanwhile, the Army, believing that World War II validated its doctrine while hoping for more

\footnotetext{
${ }^{13}$ Thomas Hanson, Combat Ready? The Eight U.S Army on the Eve of the Korean War (College Station TX: Texas A\&M University Press, 2010), 20-31.

${ }^{14}$ Linn, Elvis's Army: Cold War GIs and the Atomic Battlefield, 40-44.

${ }^{15}$ Charles Heller and William Stofft, eds., America's First Battles 1776-1965 (Lawrence KA: University Press of Kansas, 1986), 274.

${ }^{16}$ Linn, Elvis's Army: Cold War GIs and the Atomic Battlefield, 10.
} 
resources sometime in the future, failed to revise doctrine to accommodate reduced resources. ${ }^{17}$ Simultaneously, the Army contended with its new global role involving large far-flung garrisons in Europe and Asia. These circumstances caused massive personnel and equipment shortages. As a result, America's frontline units struggled to maintain their tables of organization and equipment. Critically understrength, they lacked the capability to train or fight in the emergent Cold War battlespace, especially in the Third World. ${ }^{18}$

At the same time, many battle-tested junior leaders departed the Army for civilian life. The post-war economic boom and generous government programs for education and housing siphoned away experienced leaders the Army needed to conduct effective large-scale training. Many replacing them often were reluctant and uninterested in a soldier's life as a good economy and persistent strands of anti-militarism in American society made the military, especially the infantry, an unattractive option for many young people. Many enlisted voluntarily, but usually to avoid the draft, or to gain technical training for a civilian career rather than actually wanting to fight a war. ${ }^{19}$

To make matters worse, the conscription system contained structural issues carried over from WWII. The assignment process, based largely on aptitude test scores, gave technical branches including the newly formed Air Force priority for well-educated conscripts. Intelligent inductees typically had the option to avoid the Army's combat arms branches in favor of technical specialties that were valuable in civilian life. ${ }^{20}$ As a result, the infantry lacked

\footnotetext{
${ }^{17}$ Christian Jaques, "United States Army Infantry Training Program Effectiveness During the Korean War" (Fort Leavenworth KA, U.S Army Command and General Staff College, 1995), 98-100, https://apps.dtic.mil/sti/pdfs/ADA313127.pdf.

${ }^{18}$ Hanson, Combat Ready? The Eight U.S Army on the Eve of the Korean War, 34-44.

${ }^{19}$ Lisa Mundy, American Militarism and Anti-Militarism in Popular Media 1945-1970 (Jefferson NC: McFarland and Company Inc., 2012), 28-37.

${ }^{20}$ George Flynn, The Draft 1940-1973 (Lawrence KS: University Press of Kansas, 1993), 126, 234.
} 
experienced personnel to conduct training as well as intelligent, top-shelf, and easily trainable recruits to turn into high-quality soldiers. ${ }^{21}$

The unique nature of the Korean War exacerbated these weaknesses in the infantry, based as they were on the general contempt Americans had for ground warfare. Americans have long been, and remain, a people unusually preoccupied by morality. They are thus often skeptical, if not apathetic, toward wars fought for reasons of policy rather than for some righteous cause. So it was with Korea, despite policymakers' efforts to turn it into a crusade against communism. The American public quickly lost interest in the war after its first entertaining summer and the subsequent defeat in winter. This apathy extended to the conscripted soldiers whose morale was undermined by a lack of convincing purpose and the distinct feeling that no one cared about them. $^{22}$

For these reasons, this thesis argues that the attitude of American society towards ground war, both in general and in Korea specifically, was the root source of not only problems with infantry training, but also several other factors influencing the outcome of the war. None of this, however, is to suggest that Americans "went soft" or that their society had somehow become corrupted. Rather, Americans, given their peculiar attitudes towards war, lacked the temperament as a society to confront the military problem of the Korean War.

In reaching such a conclusion, which directly links cultural attitudes about warfare to military policy and battlefield effects, this analysis places itself firmly within the discipline of war and society. This interdisciplinary approach examines the hinges of culture, policy, and memory that connect a society to the battlefield. The necessity of taking this approach towards

\footnotetext{
${ }^{21}$ Hanson, Combat Ready? The Eight U.S Army on the Eve of the Korean War, 20-21.

${ }^{22}$ Melinda Pash, In the Shadow of the Greatest Generation (New York, NY: New York University Press, 2012), 124 25.
} 
this particular historical question is explained in the first chapter of this analysis which explores the historiography of Korean War training.

The second chapter evaluates the recruitment and training of U.S. Army soldiers from just after WWII until the start of the Korean War. The chapter begins with a discussion of recruitment and conscription before moving on to discuss the Army's training programs. Throughout, the chapter demonstrates how the Army's recruitment and training system had significant problems that later impacted combat performance in Korea. Furthermore, the chapter shows how public attitudes regarding the Army and ground warfare undergirded these issues. To reach these conclusions, the chapter's analysis follows a specific methodology.

First, the chapter discusses recruitment because societies are not homogenous and how they sort different groups into military service impacts training's ultimate outcome. If one likens military training to a manufacturing process, then recruits resemble highly differentiated raw materials that dramatically alter the final product. How and why societies evaluate and select these materials for military purposes reveal a starting point for the training process and sheds light on the priorities and attitudes of the wider society towards military affairs.

In evaluating recruiting for the Army, this analysis shall focus on three criteria: quality, quantity, and distribution. In other words, does the military get who it wants, in the numbers it wants, and do they go where it needs them. It is important to note that this analysis focuses its evaluation on the military aims of recruitment policy. Although scholars such as Amy Rutenberg have established that military recruitment policy tried to implement social engineering through manpower channeling, that only served civilian priorities and has little bearing on evaluating the combat outcomes of recruitment practices. ${ }^{23}$

${ }^{23}$ Amy Rutenberg, Rough Draft: Cold War Military Manpower Policy and the Origins of Vietnam-Era Draft Resistance (Ithaca: Cornell University Press, 2019), 94. 
After recruitment, follows an evaluation of the training that turned recruits into infantrymen. There are two important elements of training: the basic training that recruits received upon joining the service and the training later given as part of their units. The chapter evaluates both on four criteria. The first is curriculum which involves answering questions like what the Army included in instruction, its relevance or usefulness and the intended goals. Next is organization or how training is carried out and by whom. Organization also reviews the division of instructor labor between different tasks and the existence of a realistic timetable. Third is execution which involves carrying out instruction. For quality training, instructors must correctly follow their guidelines and ensure competent execution by cadre that guarantees positive outcomes. The final criterion is effects which determines what effect instruction has on the soldier, how the preceding points impact the goals of the training and whether, training accomplished its goals.

Although this evaluation concentrates on the infantry, it includes all soldiers as many of those who fought in Korea nominally belonged to different MOSs. Additionally, this analysis will focus on Army training to the exclusion of marines, airmen, and sailors for two reasons. First, Army personnel made up the vast bulk of the troops employed in combat and eventually captured, making them the service most relevant to the overall effectiveness of U.S military forces in the war. Second, commentators usually single out the Army for poor performance in Korea while sparing other services, making the Army more relevant to the question of recruitment and training. ${ }^{24}$

Similarly, this analysis generally will not make direct comparisons between the training of separate services, for example, the Army and Marine Corps. Such a comparison is a separate

\footnotetext{
${ }^{24}$ Fehrenbach, This Kind of War: The Classic Korean War History, 128.
} 
argument from evaluating a program on its own merits as this analysis does. Furthermore, comparing organizations with completely different, sizes, missions, and cultural identities can easily lead to fallacious conclusions. Finally, numerous other scholars have made such comparisons and there is a danger of being redundancy and retreading their work. ${ }^{25}$

After evaluating U.S. Army recruitment and training, the third chapter analyzes their impact on battlefield outcomes. Unlike the topically organized second chapter, the third chronologically follows the narrative of the Korean War. This allows it to assesses changes made to training and recruitment during the war and how they affected troop performance. At the same time, the chapter explores additional factors that affected the course of the war, demonstrating how they also connect back to Americans' social attitudes towards war. Ultimately, the chapter shows how a variety of deficiencies caused the U.S. Army's failures in Korea, and that they resulted from an American society poorly disposed to waging modern ground warfare.

Afterwards, this analysis will conclude with a brief overview of the Army's deficiencies in training, how those deficiencies impacted combat performance, and additional factors that played a role in American defeats. Additionally, it will discuss the implications of these findings for modern policy makers, thus showing the need for the wholistic approach of war and society in interpreting the lessons of past conflicts and applying them into the future. Finally, is a brief exploration of what these findings mean in the context of the historiography of the Korean War and the need for additional research.

\footnotetext{
${ }^{25}$ Linn, Elvis's Army: Cold War GIs and the Atomic Battlefield, 197-98.
} 


\section{Dissecting Defeat}

Even in the earliest months of the Korean War, its transmutation from lived experience into public memory and cultural mythology started. It began with war journalism that conveyed battlefield events to the American people. Such early drafts of history were not very good. According to one journalist's analysis, the war correspondents initially proved good and objective, but as the U.S. military pressed for a popular portrayal, the journalists quickly began writing the official government narrative which was largely propaganda. ${ }^{26}$ Historian Theodore Fehrenbach was blunter in his assessment. He exclaimed that "rarely has a conflict been so badly reported." 27 As a result, the fairly accurate stories of Task Force Smith, with its undersized, underequipped American force facing large numbers and tough Soviet tanks, became the de facto templates for future coverage of American defeats. ${ }^{28}$

It was not long before the war depicted in the papers reached ridiculous proportions. The primary theme became invincible oriental hordes equipped with Soviet superweapons. For example, one New York Times article published approximately a week after the initial contact between American and North Korean forces quoted an American company commander saying "Man for man, we are better by at least fifteen to one. So far it is a thousand to one." It further claimed "sixty-ton, heavily armored Soviet tanks" led the advance ${ }^{29}$ It was a ridiculous claim as

\footnotetext{
${ }^{26}$ Phillip Knightley, The First Casualty: The War Correspondent as Hero and Myth-Maker from the Crimea to Iraq, Third Edition (Baltimore: John Hopkins University Press, 2004), 365-90.

${ }^{27}$ Fehrenbach, This Kind of War: The Classic Korean War History, 103.

${ }^{28}$ Roy Macartney, "YANKS FLEE 40 RED TANKS LEAVE WOUNDED ON FIELD: Survivors Describe 4 Hour Clash Near Osan," Chicago Daily Tribune, 6 July, 1950; Walter Simmons, "GIs FIGHT ON UNTIL AMMUNITION IS EXHAUSTED; ABANDON BIG GUNS: Tribune Man Tells How Howitzers Shelled Foe," Chicago Daily Tribune, 6 July, 1950.

${ }^{29}$ Richard Johnston, "Korea Shakes G.I.'s Faith In U.S. Arms Superiority: G.I.'S FAITH SHAKEN IN U.S. SUPERIORITY Spearheaded by 60-Ton Tanks One of Biggest Headaches," New York Times, July 13, 1950.
} 
the T-34-85 medium tanks comprising the North Korean tank corps were just slightly more than half that weight. ${ }^{30}$

These exaggerations continued after the Chinese intervened in the conflict. This new foe inflated American public estimates of the enemy numbers. Some contemporary journalists such as Reginald Thompson and Michael Davidson derisively dismissed such characterizations, however, most parroted the official line. ${ }^{31}$ In actual fact, the communist forces merely reachieved parity with the U.N in force size after the severe losses of the North Korean Army. ${ }^{32}$ Still, U.S. journalists continued writing that the enemy dramatically outnumbered U.S. troops. By that point many people acknowledged the Americans had the advantage of equipment so some attributed battlefield defeats to a lack of U.S. manpower. ${ }^{33}$

As an impending armistice emerged into reality in 1953, U.S. analysts consistently began to view the Korean War as a failure for not really altering the larger Cold War struggle. Early editorials after the armistice, including one written for the New York Times by Hanson Baldwin, tried navigating the nuances and complexities of the war's ambiguous ending to identify its place in history. For Baldwin, the war's ambiguity prevented characterizing it as either victory or defeat. ${ }^{34}$ However, the fact remained that the Americans had not won the desired triumph.

In the years after the war, many analysts agreed with initial impressions. As historian Brian Linn put it, "for many soldiers at the time, the Korean Armistice Agreement of 27 July

\footnotetext{
${ }^{30}$ Fehrenbach, This Kind of War, 465-66.

${ }^{31}$ Bruce Cumings, The Korean War: A History (New York, NY: Modern Library, 2011), 29; Knightley, The First Casualty, 373.

${ }^{32}$ Cumings, The Korean War: A History, 29.

33 "Numbers Will Win Present Korea Battle, Reporter Says, and Chinese Reds Have Them," The Washington Post (1923-1954); Washington, D.C., 30 November, 1950, 2; "2-Way Traffic: Retreat and Advance: WARN YANKS' POSITION MAY BE UNTENABLE," Chicago Daily Tribune, 3 December, 1950.

${ }^{34}$ Hanson Baldwin, "Not Victory, Not Defeat: But Another War, Marked by Shining Deeds as Well as Misery, Passes Into History," New York Times, 28 July, 1953.
} 
1953 was a poor substitute for victory. ${ }^{\circledR 3}$ Correspondingly, most viewed the Korean War as a defeat more than anything else. This dissatisfaction quickly gained traction in popular media. Comic books depicted Korean battles with harsh realism and movies such as The Bridges at Toko-Ri and Pork Chop Hill adopted a bleak fatalism, contrasting dramatically with Worl War II films. ${ }^{36}$

Ambitious goals of trying to destroy the DPRK and conquer North Korea rather than simply defending South Korea helped ensure that Americans perceived the war as a failure. WWII and the concept of unconditional surrender had become the benchmark for victory to most Americans. ${ }^{37}$ Over time this judgment of the Korean War as a failure evolved. Later commentators and contemporary witnesses noted that, in preserving South Korea, the United States had met its initial objectives of containment and scored an important early success in the Cold War. ${ }^{38}$ Nonetheless, the United States failed to destroy North Korea and stop the continued division of Korea which in the eyes of most Americans was a poor substitute for victory.

Afterwards, with the Korean War fixed in the American psyche as a failure, journalists and other commentators sought to explain the defeat. These critiques of the war generally branched into one or both of two distinct arguments: one blaming civilian society and another the military establishment. The first critique generally attributed the failures of the Korean War to some kind of decay of American society, something had made the young American soldiers soft and weak by living in an overly permissive and indulgent world. This was a major theme in Fehrenbach's This Kind of War: The Classic Korean War History. Originally subtitled A Study in

\footnotetext{
${ }^{35}$ Linn, Elvis's Army: Cold War GIs and the Atomic Battlefield, 52.

${ }^{36}$ Mundy, American Militarism and Anti-Militarism in Popular Media 1945-1970, 63-67.

${ }^{37}$ Fehrenbach, This Kind of War, 180.

${ }^{38}$ Linn, Elvis's Army, 52; Stickle, So They Will Know, iii.
} 
Unpreparedness when it was published in 1963, it became a standard history for the U.S armed forces. ${ }^{39}$

However, more incendiary social critiques arose, many dealing with the issue of POWs. Chief among such works was Eugene Kinkead's In Every War But One. Kinkead, a journalist, wrote this influential work in 1959 after the Army granted access to their investigations into POW misconduct. His conclusions were harsh. According to Kinkead, U.S soldiers who became POWs suffered extraordinary death rates largely as the result of their own lack of discipline and toughness in manageable circumstances. ${ }^{40}$ Furthermore, Kinkead, in several lengthy diatribes, pointed to a growing softness in American society which left soldiers vulnerable to psychological seduction by savvy communist cadres. These arguments, often intersecting with fears of communist infiltration and influence over the young in Cold War America, found a wide audience and significantly influenced contemporary thinking about the war. ${ }^{41}$

The critique of America's civilians was broad and often intersected with popular political rhetoric. However, the post-war critique of the military establishment was significantly narrower and concentrated on issues of military performance. Critics tended to portray wartime defeats as originating from a military failure to properly prepare for battle. To these people, the Army's leaders allowed standards to slip which ensured the series of defeats in Korea. Their focus was not on the quality of the larger American citizenry, but on military officials responsible for the proper functioning of the armed forces. Occasionally, this criticism narrowed even further to the commanders of Eighth Army, that provided the bulk of the U.S. troops in Korea. Unlike the

\footnotetext{
${ }^{39}$ Fehrenbach, This Kind of War, 66.

${ }^{40}$ Eugene Kinkead, In Every War But One (Westport, CT: Greenwood Press, 1959), 17.

${ }^{41}$ Kinkead, 90-96; Latham, Cold Days in Hell: American POWs in Korea, 241-42.
} 
more amorphous social critique, this military critique placed the blame for battles like Task Force Smith squarely on a relatively small group of leaders.

Two government sources highlight the influence of this argument. First, a 1952 propaganda film titled "We Never Stop," an episode of the Army's weekly The Big Picture television program, sought to counter the notion that the Army's prewar training faltered and to reassure Americans of its readiness for war. Throughout its runtime, the film emphasizes Army training's realism and uniform worldwide standards to specifically address the criticisms that it lacked both. Despite admitting that American soldiers lacked preparation for "this kind of fighting," the narrator assured the audience that training had improved to account for communist tactics. ${ }^{42}$ They implied novel communist tactics, not a failure to practice basic fundamentals of war, caused the Army's initial defeats. The film underscored that even in 1952, the Army wanted to publicly challenge perceptions that it had been lax in its readiness.

By the 1960's however, the Army shifted its position somewhat regarding its performance in Korea. Released in 1961, Roy Appleman's South to the Naktong, North to the Yalu was the first part of the Army's official history of the war. In it, Appleman gave a wartsand-all account of the Army's performance, acknowledging significant failures at all organizational levels. Regarding training in the Eighth Army prior to the Korean War, Appleman was blunt. "A basic fact is that the occupation divisions were not trained, equipped, or ready for battle." ${ }^{43}$ With the war in Korea behind it and the necessity of keeping the public on-side diminished, the Army willingly, perhaps even eagerly, noted its shortcoming in training prior to the war.

42 We Never Stop, The Big Picture (U.S. Army Signal Corps, 1952), Periscope Film LLC, \#52304, https://www.youtube.com/watch?v=nu1IdPpGipc\&list=PLqqqqZrD37h6YXQMqKLVngvya6CfiDb9X\&index=41.

${ }^{43}$ Roy Appleman, South to The Naktong, North to The Yalu (Washington, D.C.: Center of Military History, U.S. Army, 1961), 180. 
Training was only one object of criticism in early commentaries on Korea. In his 1953 book The River and the Gauntlet, historian S.L.A. Marshall, a consultant with Eight Army's operations department (G3) throughout the war, challenged existing narratives on what caused the U.S. retreat during the Chinese November offensives. Marshall emphasizes the American GI was neither cowardly nor unprepared, but struggling in the face of exceptional hardship. ${ }^{44}$ To Marshall, the commanders, not the GIs, caused the failures.

Specifically, Marshall blames mistaken intelligence estimates and poor disposition of Eighth Army's logistics for making the Eighth Army vulnerable to the shock and panic following surprise attacks. Although not saying it outright, Marshall's positive portrayal of Lieutenant General Walton Walker and his staff suggests his criticism focused on General MacArthur and the staff of General Headquarters in Tokyo. In this critique, the failures revolved around the high-ranking officers running the campaign, not training. ${ }^{45}$

Several years later, in 1963, Fehrenbach's This Kind of War codified and linked the military and social critiques of the U.S Army's performance in Korea. He believed aspects of the American society weakened its military capability and negatively impacted its troops in Korea. However, Fehrenbach contended that occurred because of the shortcomings and failures of military leaders. In an argument oddly reminiscent of H.R. McMaster's work on the behavior of the Joint Chiefs of Staff during the Vietnam War, Fehrenbach belittled senior military officers for cowardly surrendering to the unreasonable public demands and not challenging "petty interference" from elected officials. It was this failure on the part of military leadership that degraded in the standards of training and discipline in the infantry. ${ }^{46}$

\footnotetext{
${ }^{44}$ Marshall, The River and the Gauntlet (Westport, CT: Greenwood Press, 1953), 34-40.

${ }^{45}$ Marshall, 10-16.

${ }^{46}$ Fehrenbach, This Kind of War: The Classic Korean War History, 172.
} 
It is important to note here that although Fehrenbach links the social critique to the military one, he never merges these arguments. Rather, Fehrenbach describes social decay and the failure of military commanders to prepare as coexisting, yet separately causing the failures in Korea. He emphasized, "Soldiers fight from discipline and training, citizens from motivation and ideals. Lacking both, it is amazing that the American troops did even as well as they did." ${ }^{\prime 4}$ The soldiers of Task Force Smith were doubly unfortunate. They arose from a society that made them unsuited for war and entered a military unwilling or unable to undo society's conditioning. As a result, they ran and they died.

In both these critiques, the authors consistently compared Korea to World War II. Whether expressed implicitly or explicitly, commentators tended to use "the good war" as the benchmark for combat performance, training rigor, and public engagement vis-à-vis the war in Korea. For example, Kinkead compared American POWs in WWII and Korea based on their escape and death rates. ${ }^{48}$ Fehrenbach also used World War II as a benchmark, although less explicitly than Kinkead. When voicing criticism, he too occasionally made direct comparisons between the soldiers, civilians, and policies of Korea and those of World War II. ${ }^{49}$ In effect, both critiques juxtaposed the two conflicts, arguing that if Americans followed WWII practices, the outcome in Korea would have been better for the United States.

Over the years the comparative critiques of the Korean War have steadily eroded as scholars reevaluated the efficacy of America's World War II Army. Simply put, World War II went worse than Korean War critics remembered. In historian Peter Mansoor's study of the U.S. Army's performance in World War II, he notes that unit training and combat exercises often

\footnotetext{
${ }^{47}$ Fehrenbach, 102.

${ }^{48}$ Kinkead, In Every War But One, 16-17.

${ }^{49}$ Fehrenbach, This Kind of War: The Classic Korean War History, 59, 224.
} 
lacked, quality, realism, and consistency, especially early in the war. ${ }^{50}$ Additionally, the recruitment and training of replacement troops in World War II (essentially the model for Korean recruitment) had severe defects in administration and training effectiveness, leading to extreme casualty rates for those GIs who went through it. ${ }^{51}$ When these issues are considered instead of papered over, the Korean War training situation does not seem quite as disastrous or inexplicable.

One finds a similar situation when one compares civil society in the two wars. Despite critics of Korea highlighting a decline in public enthusiasm after World War II, especially in willingness to serve in combat, evidence suggests much public disinterest existed in both conflicts. As Amy Rutenberg pointed out, forty percent of Americans in 1944 did not know why the U.S fought and many Americans retained negative perceptions of military service.$^{52}$ There was also widespread draft avoidance that went relatively unnoticed. Instead of resorting to mass protest or criminal avoidance, many military aged males and their families exploited the deferment system to avoid service. This problem was so severe that caused a manpower shortage by $1944 .{ }^{53}$ Even in terms of civil engagement, World War II was hardly the exemplary model of excellence often portrayed in the literature.

Nonetheless comparisons between the U.S. Army in World War II and Korea have merit. Fighting in the two wars was very similar. Both sides in Korea largely used World War II era equipment, technology, and tactics. In World War II U.S. soldiers also fought and succeeded in several situations broadly similar to those that they found in Korea. In both wars U.S. troops

\footnotetext{
${ }^{50}$ Peter Mansoor, The GI Offesnive in Europe: The Triumph of the American Infantry Divisions, 1941-1945 (Lawrence KS: University Press of Kansas, 1999), 24-31.

${ }^{51}$ Mansoor, 43-45.

${ }^{52}$ Rutenberg, Rough Draft: Cold War Military Manpower Policy and the Origins of Vietnam-Era Draft Resistance, 17.

${ }^{53}$ Rutenberg, 28-35.
} 
fought in broken or mountainous terrain (the bocage of Normandy and Italy) and defended against a surprise enemy offensive during a frigid winter (the Battle of the Bulge). ${ }^{54}$ To compare the two wars seems fairly reasonable from this perspective.

However, enough differences make comparisons problematic. The two wars were very different in scale, objectives, and progression. The operational and tactical situations and limitations U.S troops encountered in Korea differed significantly from those in World War II. Differences also created unique home front environments for each. Thus, the Korean War should be evaluated on its own terms without relying too much on potentially spurious comparisons to other conflicts. Even without comparisons with the Second World War though, the two major critiques of Korea remain compelling arguments requiring analysis and understanding.

Naturally then, people continued critiquing these two ideas. In particular, scholars hammered the social decay thesis. Kinkead's work, a sensationalist story, quickly became a target. By 1963, people such as Albert Biderman, have demonstrated Kinkead's work had inaccuracies, misquotes, and contrived statistics, thoroughly discrediting it. ${ }^{55}$

However, Ferhenbach's social critique proved more resilient, though no less controversial. Even over fifty years later they remain contested. Distinguished historian Brian Linn had challenged Fehrenbach in recent years. Linn connected Fehrenbach and Kinkead, characterizing their arguments, and similar ones on the impact of American civilian culture on the military, as spurious, self- serving, and convenient. ${ }^{56}$ To Linn, the argument that the character of American society significantly shaped battlefield results constituted a collective effort of

\footnotetext{
${ }^{54}$ Mansoor, The GI Offesnive in Europe: The Triumph of the American Infantry Divisions, 1941-1945, 106-10, 218219; Michael Doubler, Closing With the Enemy: How GIs Fought the War in Europe (Lawrence KA: University Press of Kansas, 1994), 39, 206-209.

${ }^{55}$ Latham, Cold Days in Hell: American POWs in Korea, 242.

${ }^{56}$ Linn, Elvis's Army: Cold War GIs and the Atomic Battlefield, 11.
} 
senior officers to deflect blame away from themselves for the war's early defeats. Specifically referencing Fehrenbach, Linn caricatures This Kind of War as "a moral fable in which wise generals had warned of the communist danger, but frivolous and selfish civilians had disregarded their sage counsel and emasculated the armed forces." ${ }^{, 57}$

One might think Linn doth protest too much. Fehrenbach's central argument portrayed American civilians as frivolous and selfish people who emasculated the Army and many of his most famous passages and quotable lines specifically address this issue. ${ }^{58}$ However, Fehrenbach critiqued both civilian society and military leadership. A careful reading of his book reveals the many deficiencies of the Army's generals. Fehrenbach portrayed senior military leaders as selfabsorbed, out of touch, and lacking moral courage. And he often named them. ${ }^{59}$

Nevertheless, Fehrenbach contended professional soldiers "still know better than anyone else how a war is won. ${ }^{960}$ However, he acknowledged the faults and failures of professional soldiers and the need for oversight by competent civilian authorities. In fact, his most damning indictments of U.S. political leaders revolved around allowing General Douglas MacArthur too mисh authority in the decision-making regarding the political and diplomatic aspects of the war. ${ }^{61}$ Thus, Linn's criticism of Fehrenbach is not entirely fair.

Nonetheless, criticism by Linn and others successfully pokes holes in the social decay thesis. They rightly point out many perceived novelties of Korean War GIs had powerful antecedents and the social critique lacked validity. Furthermore, although Linn likely overstated things, his skepticism had validity for challenging the social critique because it emerged so close

\footnotetext{
${ }^{57}$ Linn, 70.

${ }^{58}$ Fehrenbach, This Kind of War: The Classic Korean War History, 289-303. Fehrenbach's Chapter 25 "Proud Legions," where he takes a long aside from the narrative of the war to discuss his views on civil-military relations, is sometimes held up as exemplary of the work as a whole.

${ }^{59}$ Fehrenbach, 102.

${ }^{60}$ Fehrenbach, 299.

${ }^{61}$ Fehrenbach, 188-89.
} 
to the end of the war, World War II veterans largely made it, and its intersection with concurrent political themes. From this, it is fair to say that the social critique of the Korean War Army, although not exactly discredited, has lost ground over the years.

In contrast, many academics fully embraced the military critique, placing the nexus of failure within the military leadership. Focusing on racist assumptions that led to underestimation of the enemy, a fixation on technology and "push-button warfare," and failed manpower, equipment, and training policies in Korea, historians and others have accepted these claims as essentially gospel. ${ }^{62}$ Linn succinctly describes this consensus, stating: "On the eve of the Korean War, the U.S. Army was less a coherent instrument of national defense than a patchwork of organizations and individuals wearing the same uniform." ${ }^{\text {63 }}$ As a result little scholarship on the Korean War seriously addresses this conception.

But dissent continues, primarily by a small group of soldier historians seeking to counter the military critique of the Korean War. Thomas Hanson's Combat Ready: The Eight Army on the Eve of the Korean War has led the way in a monograph that unabashedly attempts to rescue the reputation of the Eighth Army from the unwarranted criticism from Fehrenbach and Appleman regarding the quality of its training. ${ }^{64}$ Through his analysis of training records, Hanson shows reforms to training in the late 1940s actually addressed most issues which Appleman and Fehrenbach identified. However, although Hanson convincingly showed improvements in training in Eighth Army, he failed to demonstrate that the training ever reached a truly acceptable level.

\footnotetext{
${ }^{62}$ Cumings, The Korean War: A History, 14-17; Stanley Sandler, The Korean War: No Victors, No Vanquished (Lexington KY: University Press of Kentucky, 1999), 8-13; Linn, Elvis's Army, 47; Melinda Pash, In the Shadow of the Greatest Generation (New York, NY: New York University Press, 2012), 60.

${ }^{63}$ Linn, Elvis's Army: Cold War GIs and the Atomic Battlefield, 47.

${ }^{64}$ Hanson, Combat Ready? The Eight U.S Army on the Eve of the Korean War, 7-12.
} 
Hanson's arguments have limitations. He closely analyzed better units such as the $27^{\text {th }}$ Infantry Regiment while ignoring underperforming ones such as the $34^{\text {th }}$. Additionally, he tries to spin unflattering evidence of problems as outside of the Army's control. In his discussion of the Army's fitness program, Hanson argued the very presence of the program absolved the Army of responsibility for deficient physical fitness among its soldiers. He ignores the obvious conclusion that the Army should shoulder the blame for failing to consistently implement its own program. ${ }^{65}$

Ultimately, Hanson, like other soldier-scholars studying the issue, failed to convincingly counter the military unpreparedness thesis. In fact, Hanson's conclusion roughly admits that Eighth Army lacked preparedness and tried blaming political leadership, an argument oddly reminiscent of the caricaturized version of Fehrenbach's argument portrayed by Linn ${ }^{66}$ Despite such efforts, the critique that the U.S military establishment failed to prepare itself for the Korean War has persisted more stubbornly than has the social critique.

As scholarly debates continue, the initial two critiques have become one dominant view that the battlefield failures of the Army resulted from the military establishment's failure to properly train and prepare its forces for battle. Scholars rightly question early social critiques of the Korean War Army and there are good reasons to criticize the Army's training system as my subsequent analysis shows. However, this military-centric orthodoxy also remains problematic.

By implicitly treating the battlefield failures in Korea as a purely military issue, scholars limit their depth of analysis. It is easier for scholars to place battles in a vacuum outside social norms and pressures and concentrate on generals held accountable by the public. However, in doing so, they forget people who fight wars remain products of their society. By discounting of civilian society's impact on the conduct of soldiers in the Korean War, scholars ignore a crucial

\footnotetext{
${ }^{65}$ Hanson, 41-44.
}

${ }^{66}$ Hanson, 109-17. 
aspect of that war's history. Criticizing one's own way of life makes people uncomfortable but all social systems have weaknesses, and acknowledging them regarding the waging of war in no way invalidates overall strengths. It is for these reasons that infantry training prior to the Korean War needs reexamination with an eye towards the role of society. 


\section{Means and Ends}

Late on the evening of June $10^{\text {th }}, 1950$, Joseph DeHaan was on his way back to Fort Ord California where he was stationed for basic training. Discipline at Ord was lax. DeHaan and his buddies regularly left post on the weekends in civilian clothes to go watch movies or have a drink at the local bar. ${ }^{67}$ On occasion the recruits' off-post activities even extended to gambling. ${ }^{68}$ This night, DeHaan was returning from a corny western romance film when he encountered his platoon sergeant who was blind drunk. ${ }^{69}$ It was unusual to encounter the sergeant at this hour. He normally coped with his impending divorce off-post with the company's other four sergeants, leaving the recruits to their own devices. ${ }^{70}$

After fending off his sergeant's drunken efforts to promote him, DeHaan returned to the barracks and thought about the future. His training was ending soon, and he was looking forward to a furlough and an easy posting where he could learn a good trade before getting out. ${ }^{71}$

Unfortunately, DeHaan never left the Army. In August of 1953, Dehaan's family finally received confirmation of why he stopped writing in 1951. Joseph Dehaan was captured by the Chinese on the front lines of the Korean War and later died in a prison camp. ${ }^{72}$ Joseph DeHaan's story is, sadly, not unique. Hundreds of thousands of young Americans joined the Army between 1946 and 1950, most of them believing that they would never see battle. Instead, many of them died in

\footnotetext{
${ }^{67}$ Joseph DeHaan to Dorothy Page, May 12, 1950, Joseph DeHaan Korean War correspondence (2015.084.w.r), Center for American War Letters Archives, Chapman University, CA. (hereafter DeHaan Correspondence).

${ }^{68}$ DeHaan to Page, May 8 1950, DeHaan Correspondence.

${ }^{69}$ DeHaan to Page, June 11 1950, DeHaan Correspondence.

${ }^{70}$ DeHaan to Page, May 31 1950, DeHaan Correspondence.

${ }^{71}$ DeHaan to Page, June 11 1950, DeHaan Correspondence.

72 Telegraph from Mrs. Dehaan to Dorothy Page, Aug 16 1953, DeHaan Correspondence.
} 
defeat after defeat, in in a war they were entirely unprepared to fight. Their unpreparedness represents one of the greatest failures in U.S. military history.

Before arriving in Korea, American GIs experienced three processes which shaped their character as soldiers. They included the Army's recruitment process which selected and pulled the soldier, willingly or not, out of the civilian world and into the military. Next, they endured basic training which transformed the civilian into a soldier and imparted basic skills to function in his new role. Finally, newly minted soldiers at their first posts learned advanced skills through their unit's training program. ${ }^{73}$ These processes sought to create a motivated and capable warrior. Therefore, if American soldiers performed poorly in combat, the source of that deficiency reflected a defect within one or more of these processes.

Recruitment entailed the first interaction of any soldier with the military. The single most important component of the U.S. military's recruitment system before and during the Korean War was the Selective Service System (SSS), colloquially known as the draft. This system managed conscription, trying to provide the military with a large force of citizen-soldiers ideally as quickly and equitably as possible. Although the United States utilized large scale conscription in past wars, the system that recruited soldiers for the Korean War largely reflected lessons from World War II.

In September of 1940, the U.S. government reacted to war in Europe and the rising threat of totalitarianism with the first peacetime draft in American History. The system set up by the Selective Training and Service Act of 1940 created the template for conscription before and during the Korean War. Men aged 21 to 36 had to register and receive classification according to their fitness and occupation from local draft boards. In 1940, if a man received notice and lacked

\footnotetext{
${ }^{73}$ Linn, Elvis's Army: Cold War GIs and the Atomic Battlefield, 42.
} 
one of several deferments and exemptions, he had to complete one year of active service in the military followed by ten years in the reserves. ${ }^{74}$

Over the course of WWII, the specific parameters of the draft fluctuated due to military necessity and political pressure. As manpower needs climbed, the term of service lengthened, the minimum age of registration and induction dropped to 18 , and the number and types of deferments available changed. ${ }^{75}$ Throughout the war, issues of who should serve and for how long remained controversial and politicians constantly debated over the execution of the draft. ${ }^{76}$ Nonetheless, the draft successfully inducted approximately 10 million citizens with remarkably equity in regard to class and education by the war's end in $1945 .^{77}$

Despite its success, many Americans viewed conscription as an expedient and expected it to disappear when the war ended. However, with the end of WWII, the United States acquired significant military responsibilities abroad. It needed to maintain a large garrison force to occupy Germany and Japan as well as project enough military power to deter increasing Soviet aggression. Ultimately, to maintain these forces while also releasing veterans of the war to return home, Congress reluctantly extended the draft until April $1947 .^{78}$

When that date came, however, government officials allowed the draft to expire, partly motivated by domestic political concerns. Labor unions opposed the draft because it ensnared their constituency and threatened their jealously guarded influence. African American organizations opposed the draft because it remained, like the Army itself, a segregated

\footnotetext{
${ }^{74}$ Flynn, The Draft 1940-1973, 18-19.

${ }^{75}$ Rutenberg, Rough Draft: Cold War Military Manpower Policy and the Origins of Vietnam-Era Draft Resistance, 28-32.

${ }^{76}$ Rutenberg, 30-37.

${ }^{77}$ Flynn, The Draft 1940-1973, 85-86.

${ }^{78}$ Linn, Elvis's Army, 31; Flynn, The Draft 1940-1973, 89-95. The extended draft exempted 18-year-olds and shortened the tour of duty to 18 months. It was only passed after recruiting shortfalls threatened to derail the demobilization of those already in the military.
} 
organization. Additionally, the newly independent Air Force argued that its nuclear-armed bombers made large ground armies unnecessary - thus undermining the need for conscription. Finally, the White House and the Pentagon preferred volunteers to fill the ranks of the post-war Army. ${ }^{79}$

With few choices, the military establishment fell back on its traditional volunteer-based recruiting system. ${ }^{80}$ This system operated in parallel to the draft early in WWII undergirded by the preconception that volunteers made better motivated soldiers. However, in reality people often enlisted voluntarily to avoid having their branch of service decided by the draft. This created problems in the military personnel system because skilled individuals often avoided the infantry where the military needed them most. The military assignment system facilitated this by funneling those with high aptitude test scores to technical and administrative services instead of the combat arms. ${ }^{81}$ Eventually, the military suspended voluntary recruitment for the duration of the war. ${ }^{82}$ When voluntary enlistments resumed afterward, similar problems reemerged, with many soldiers exploiting loopholes to secure a shorter term of service than if drafted. ${ }^{83}$

To supplement the return to an all-volunteer force, several influential leaders including President Harry Truman advocated for Universal Military Training (UMT). UMT required all young men in the country to complete a continuous year of military training. Then they would become part of a massive reserve force quickly mobilized in the event of a major war. ${ }^{84}$ Additionally, leaders hoped that UMT would provide an opportunity for improve the character of America's young men, inoculate them with national virtues, and encourage them to volunteer for

\footnotetext{
${ }^{79}$ Flynn, The Draft 1940-1973, 97-101.

${ }^{80}$ Flynn, 89.

${ }^{81}$ Linn, Elvis's Army: Cold War GIs and the Atomic Battlefield, 15.

${ }^{82}$ Flynn, 48-54, 126, 234.

${ }^{83}$ Linn, Elvis's Army, 28.

${ }^{84}$ William Taylor, Military Service and American Democracy (Lawrence KA: University Press of Kansas, 2016), 35.
} 
the regular Army. ${ }^{85}$ Advocates for UMT hoped that this "sound and democratic principle," combined with an all-volunteer force, could provide for the national defense and develop national virtue more cheaply and ethically than full-scale conscription. ${ }^{86}$

These plans never came to fruition. An experimental UMT training center set up in January 1947 achieved mixed results. Then congressional support sputtered and died. Meanwhile, a strong civilian economy and no draft to impel potential recruits, caused voluntary enlistments to plummet. The decline in manpower threatened to cripple the Army. ${ }^{87}$ Reluctantly, Congress and President Truman reinstated the draft in June $1948 .^{88}$

The draft authorized in 1948 bill constituted the main source of soldiers for the Korean War. Similar to 1940 , men 18 to 26 years old had to register and those 19 and older faced a tour of 21 months. 18-year-olds had the additional option to voluntarily enlist for a one-year tour followed by six years of reserve service. The organization of the system remained the same as in WWII. Despite a commitment to non-discrimination on paper, the SSS and the military remained segregated. ${ }^{89}$ However, the 1948 draft law was the nucleus of the policy of manpower channeling in the early cold war.

The country's academic elites promoted manpower channeling, or the use of draft deferments to encourage men into particular civilian fields. Through an extensive lobbying effort, the scientific community successfully pushed to include extensive deferments for students in scientific and engineering fields in the 1948 draft bill. Despite charges of elitism, legislators deemed these protections necessary to secure the scientific advantage they believed critical to the

\footnotetext{
${ }^{85}$ Linn, Elvis's Army, 29-30.

86 Taylor, Military Service and American Democracy, 35-43.

${ }^{87}$ Linn, Elvis's Army, 31.

${ }^{88}$ Flynn, The Draft 1940-1973, 108.

${ }^{89}$ Flynn, 102-208.
} 
nation's security.${ }^{90}$ They tacitly acknowledged that military service was only one, and perhaps even not even the most important way, of serving one's country. This idea permeated the draft system and later expanded further to include tasks like fatherhood or farming as comparable to carrying a rifle into battle. ${ }^{91}$ It continued to influence how America selected its soldiers throughout the Korean War.

While the draft and, to a lesser extent, voluntary enlistments filled the ranks of the U.S. Army, different programs existed to supply its leaders. Traditionally, the primary source of Army officers was the U.S. Military Academy, often referred to as West Point. However, its output was relatively small and by the late 1940 's, it had garnered a deserved reputation for producing officers with more political connections and ego than skill. ${ }^{92}$ Officer Candidate School (OCS) was another officer pipeline that produced many distinguished leaders in WWII. It was also small, and its dependence on excellent volunteers from the ranks limited its prominence in the constricted post-war Army. ${ }^{93}$ These two programs alone could not create the backbone of the post-war officer corps.

That role went to the Reserve Officer Training Corps (ROTC). Temporarily shelved during WWII, ROTC had many advantages for the post-war Army. Spread across the country's universities, ROTC ensured the large numbers of well-educated leaders that planners thought necessary to fight in modern warfare. The program gave these young men training and education needed to function as officers. After graduation, they received reserve commissions making them available for service at a moment's notice. ${ }^{94}$

\footnotetext{
${ }^{90}$ Flynn, 104-7; Rutenberg, Rough Draft, 72-79.

${ }^{91}$ Rutenberg, Rough Draft, 83-84.

${ }^{92}$ Linn, Elvis's Army, 27.

${ }^{93}$ Linn, 69.

${ }^{94}$ Michael Neiberg, Making Citizen Soldiers: ROTC and the Ideology of American Military Service (Cambridge, MA: Harvard University Press, 2000), 3-5.
} 
Additionally, ROTC advocates believed that it ensured a more egalitarian, civilian ethic in the officer corps often perceived as parochial and aristocratic. For these reasons, in 1948 the Gray Committee, headed by assistant Secretary of the Army Gordon Gray, recommended that ROTC become the primary commissioning source for the U.S. Army. The Distinguished Graduate Program, which granted high performing ROTC cadets regular commissions also began in that year. ${ }^{95}$ As a result, ROTC graduates formed a major component of the Korean War officer corps.

The influence of ROTC graduates on the Korean War officer corps occurred largely due to the involvement of large number of the Organized Reserve in the conflict. Together with the National Guard, the Organized Reserves represented the final source of soldiers for the post-war American Army. As the name suggests, the Organized Reserve was an emergency force populated by people with military training, but not active-duty soldiers. They included ROTC officers, discharged WWII veterans, and doctors. They were civilians except for monthly drill weekends and annual training, although some never actually participated in such activities. ${ }^{96}$ The National Guard was a similar organization, except its units answered to their respective state's governor rather than to the Defense Department unless federalized. ${ }^{97}$ Planners expected these forces to serve as a quick reaction to a military emergency such as in Korea.

On paper, the U.S. military's overall system for recruiting personnel and managing manpower appeared sound. It had multiple pipelines designed to attract individuals from varying walks of life and with the skills the military needed. Additionally, the system tried to build a pool

\footnotetext{
95 Neiberg, 32-33.

${ }^{96}$ Melinda Pash, In the Shadow of the Greatest Generation (New York, NY: New York University Press, 2012), 7677.

${ }^{97}$ Pash, 73.
} 
of military manpower without overburdening the civilian economy. It appeared well crafted to contend with Cold War imperatives.

In actual practice, however, the recruitment system had serious issues. Although these various recruitment programs supported civilian priorities, they often failed to meet military needs. The Army struggled to recruit and retain enough people to fill its ranks, especially in regards to the most talented individuals. It had even greater difficulty compelling them to join its combat arms branches. Meanwhile, short service commitments ensured disruptive levels of turnover throughout the Army. As a result, according to historian Brian Linn, combat units found themselves utilizing "the bottom of our manpower barrel" just before the Korean War. ${ }^{98}$

This dysfunction related significantly to the unpopularity of the Army, and especially of the infantry. Although official pronouncements and public discourse indicated otherwise, WWII reinforced long-standing skepticism towards military institutions. Familiarity bred contempt among those who served in the Army during the war as they strongly disliked the service and its professional leadership. Often, they shared this opinion with their friends and families. ${ }^{99}$

The Army's hopelessly bungled demobilization program accelerated this trend after the war. The public had a front row seat as its victorious armies disintegrated as troops rioted after being stranded overseas for months. ${ }^{100}$ At the same time, numerous scandals broke regarding the corruption and aristocratic excesses of the officer corps. ${ }^{101}$ Based on such unpleasant experiences, most Americans regarded the Army as an unwelcome detour from civilian life and hesitated to volunteer. ${ }^{102}$

\footnotetext{
${ }^{98}$ Linn, Elvis's Army, 28.

${ }^{99}$ Mundy, American Militarism and Anti-Militarism in Popular Media 1945-1970, 8-11.

${ }^{100}$ Carruthers, The Good Occupation American Soldiers and the Hazards of Peace, 194-99.

${ }^{101}$ Linn, Elvis's Army, 20-23.

102 Mundy, American Militarism and Anti-Militarism in Popular Media 1945-1970, 17.
} 
The Army was not popular among top policy makers either. As Matthew Ridgway, future commander of the Eight Army in Korea, noted in his 1967 account of the war; "before Korea, all our military planning envisioned a war that would involve the world, and in which the defense of a small and indefensible peninsula would be folly." 103 Some military thinkers viewed conventional land war as obsolete, especially military principles giving the infantry primacy. Instead, the focus shifted to "technology, nuclear weapons and their delivery systems." 104 With airpower and nuclear weapons providing a cheap and easy solution to the problem of national defense, many policy experts regarded the Army as a secondary priority. ${ }^{105}$

Unloved by the people and with few political allies, the Army scrounged for men through a national personnel system built around civilian priorities. Often, the Army took almost anyone to fill vacant leadership positions for want of qualified volunteers. ${ }^{106}$ The lack of personnel was worse in the ranks. Despite widespread conscription, many units had only a fraction of their authorized strength. ${ }^{107}$ Additionally, the draft's generous deferment scheme, the military skills testing system, and competition from the Air Force and Navy, which offered training in lucrative technical fields, effectively put the Army at the back of the line for America's brightest young men. ${ }^{108}$ U.S. policymakers spread the army across the globe but failed to provide it with manpower it needed to succeed.

The Army exacerbated the problem of manpower shortages by improperly using its soldiers. In the late 1940's it remained a segregated force which limited its effectiveness. With

\footnotetext{
${ }^{103}$ Matthew Ridgway, The Korean War, paperback (Garden City NY: Da Capo Press, 1986), vi.

${ }^{104}$ Sandler, The Korean War: No Victors, No Vanquished, 8.

105 Linn, Elvis's Army, 10.

106 Personnel Conference (1949), "Personnel Conference, 23-24-25 May 1949: Summary of Presentations" (Personnel and Administration Division, General Staff, U.S. Army, 1949), 55-59, UB23 .P48 1949, U.S. Army Heritage and Education Center.

${ }^{107}$ Linn, Elvis's Army, 22-23.

${ }^{108}$ Mundy, American Militarism and Anti-Militarism in Popular Media 1945-1970, 9; Rutenberg, Rough Draft, 9495.
} 
few opportunities for employment and education in a segregated society, black men joined the military in disproportionate numbers. However, the Army steadfastly refused using such men in specialist fields or letting them fill empty positions in white combat units. It even maintained separate organization and logistics tables for segregated units. As a result, the Army effectively wasted approximately $11 \%$ of its available manpower when it desperately needed more recruits. Repeated reports from executive committees, defense conferences, and military investigative boards castigated the Army for the gross injustice and absurd inefficiency of a segregated force. Nonetheless, the Army, shielded by Secretary of the Army Kenneth Royall, refused to desegregate, even after President Truman ordered it done in $1948 .{ }^{109}$

Combat units thus remained understaffed and those in them often lacked intelligence and education. Many infantrymen in the Army's Far East Command (FECOM) scored very poorly the Army's intelligence ratings. ${ }^{110}$ Enlisted illiteracy was high and the Army accepted many new soldiers despite physical or psychological problems that normally disqualified them. ${ }^{111}$ Short enlistment periods meant that these deficiencies could not be overcome through additional education while in the Army. ${ }^{112}$ This led to a severe shortage of specialists such as signalmen, medical technicians, and engineers in forward deployed units. ${ }^{113}$

Similar shortages existed in the officer corps. The Army struggled to fill junior officer billets, especially in technical fields such as signals and medicine. Just as with the enlisted men, those the Army could recruit were often not ideal candidates. ${ }^{114}$ Many problems stemmed from how ROTC fit into the larger recruitment system. Students in ROTC effectively removed

\footnotetext{
109 Taylor, Military Service and American Democracy, 59-69; Linn, Elvis's Army, 36-37.

${ }^{110}$ Hanson, Combat Ready? The Eight U.S Army on the Eve of the Korean War, 20-21.

${ }^{111}$ Linn, Elvis's Army, 27-32.

112 Jaques, "United States Army Infantry Training Program Effectiveness During the Korean War,” 32.

113 8th Army Headquarters, "Summary of Personnel Problems from Activation to Occupation: Yokohama, Japan, 1 February 1947," 1947, 24-27, 03-8 1947 / 3, U.S. Army Heritage and Education Center.

114 Personnel Conference (1949), "Personnel Conference, 23-24-25 May 1949: Summary of Presentations," 55-59.
} 
themselves from the manpower pool through draft deferments during their education and joining the reserves afterwards. Those who performed best, and were thus eligible for regular commissions, often chose administrative fields, depriving the combat arms of top talent. Additionally, ROTC graduates had relatively short active service commitments, resulting in high turnover rates in key leadership positions. ${ }^{115}$ At all levels, the Army's new recruits lacked talent and capability.

They often also lacked motivation. Although the vast majority of the Army's new soldiers enlisted voluntarily, this did not reflect widespread enthusiasm for the service. ${ }^{116}$ From induction forward, most draftees wanted out of the Army as soon as possible. Volunteers were only marginally more enthusiastic. ${ }^{117}$ Many only volunteered for shorter enlistments, an education or steady employment. Few really desired to fight as a soldier ${ }^{118}$

This attitude reflected long held beliefs in American society regarding the military. Americans had long viewed soldiering as an undesirable lifestyle fit only for those unable to make a living elsewhere. Most viewed it positively only if it provided the possibility of learning a valuable trade or skill. This had been the case in WWII and continued through the post-war period. ${ }^{119}$ Of course, Americans have, over the course of their history, proven that they are willing to endure military service in the face of an existential crisis. However, in the absence of such an emergency that willing spirit evaporated. ${ }^{120}$ T.R. Fehrenbach summarized this attitude

\footnotetext{
${ }^{115}$ Linn, Elvis's Army, 69.

${ }^{116}$ Linn, 57. From June 1948 to January 1950, the proportion of volunteers to draftees was roughly 12 to 1.

117 "New Soldiers' Attitudes -- After Six Weeks of Training 1, Trends in Adjustment and Orientation" (Armed Forces Information and Education Division. Attitude Research Branch, 1951), U22.3 .N49 1951, U.S. Army Heritage and Education Center.

${ }^{118}$ Linn, Elvis's Army, 28-33.

${ }_{119}$ Mundy, American Militarism and Anti-Militarism in Popular Media 1945-1970, 35-37, 60-62.

${ }^{120}$ Rutenberg, Rough Draft: Cold War Military Manpower Policy and the Origins of Vietnam-Era Draft Resistance, 66.
} 
best when he wrote that "citizens fly to defend the homeland, or to crusade. But a frontier cannot be held by citizens, because citizens, in a republic, have better things to do."121

Such social attitudes towards the military clearly damaged the Army's ability to recruit desired individuals into positions most needed. When government efforts to downsize the military resulted in a mass exodus of skilled veterans and proven leaders, the Army struggled to make up its losses. By 1949 many units were horribly understrength with some supply officers pulling double or even triple duty to make up for shortfalls. In one infantry battalion, only one company was sufficiently manned to conduct daily training. ${ }^{122}$ Those personnel the Army was able to scrounge up were typically of low quality. Of the replacements the $24^{\text {th }}$ Infantry Division received in 1948, over half were illiterate. ${ }^{123}$ Few talented young men went into combat units and those who did generally did not stay long. In Far East Command the turnover rate was $43 \%$ in 1949. In terms of the numbers, quality, and distribution of recruits it could muster, the Army's recruitment and personnel system was severely deficient.

Desperate for warm bodies to fill its frontline units, the Army adapted to attract more and better men. It relaxed its disciplinary system which became less arbitrary. It also restructured its promotion system, pay schedule, and benefits to more resemble corporate America. Unfortunately, these reforms largely failed to resolve the Army's manpower predicament. ${ }^{124}$ However, they showed how the Army changed to reflect the cultural attitudes and expectations of American society.

\footnotetext{
${ }^{121}$ T.R. Fehrenbach, This Kind of War: The Classic Korean War History (Lincoln NE: Potomac Books, 2008), 60.

${ }^{122}$ Heller and Stofft, America's First Battles 1776-1965, 272; Mundy, American Militarism and Anti-Militarism in Popular Media 1945-1970, 60.

${ }^{123}$ Linn, Elvis's Army: Cold War GIs and the Atomic Battlefield, 32.

${ }^{124}$ Linn, Elvis's Army, 27-35.
} 
American social mores also influenced Army training. Policy makers and the public increasingly viewed the Army's combat role as unimportant so combat training became less of a priority. Instead, the Army focused on educating and encouraging democratic virtues in America's young men. ${ }^{125}$ The scant resources available for conducting training reflected these priorities. Additionally, a lack of public interest allowed the Army's top leadership to become complacent about the combat readiness of its troops despite warning signs of needed significant improvements. These issues resulted in substantial defects in the curriculum, organization, and execution of the Army's basic and unit-level training programs before the Korean War.

To properly contextualize these challenges requires a brief explanation of the Army's training system at the time. The maintenance of a large standing army of conscripts necessitated a two-tiered system. The Army had neither the time or resources to train entire divisions as a unit for a year as done early in World War Two. ${ }^{126}$ Instead, soldiers received a short 8-week basic training course before joining their unit with the expectation that it would teach them advanced skills for their particular job. ${ }^{127}$ Troops later practiced these skills as part of their units in regularly scheduled training that built up over time from small sessions by a single platoon to massive joint exercises involving multiple divisions. ${ }^{128}$

The individual soldier's basic training laid the foundation for later training. Standard basic training program through of the late 1940's was an 8-week, 320-hour curriculum. Designed to teach basic soldiering skills, the standard schedule dedicated more time ( 84 hours) to weapons

\footnotetext{
125 Linn, 30-34.

126 Peter Mansoor, The GI Offensive in Europe: The Triumph of the American Infantry Divisions, 1941-1945 (Lawrence KS: University Press of Kansas, 1999), 24-27.

${ }^{127}$ Hanson, Combat Ready?, 27.

128 United States Army European Command Historical Division, "Final Report, Joint Field Training Exercise (Exercise Rainbow), 11-18 September 1950” (Joint Headquarters FTX-50, 1950), U253.2.R34 F56 1950, U.S. Army Heritage and Education Center; "Individual Training in Collecting and Reporting Military Information : A Guide to Assist the Commander of a Small Unit in Promoting Realistic Training” (Office, Chief of Army Field Forces, 1951), UB250 .I53 1951, U.S. Army Heritage and Education Center.
} 
training than any other single item. Other significant time blocks included physical training (30 hours) and tactics (30 hours). ${ }^{129}$ This focus on essential combat skills appeared to indicate a proper focus on combat proficiency.

However, although the basic training curriculum initially appears reasonable, a deeper look reveals less combat focus than it may appear. New soldiers spent 99 hours engaged in training with little or no combat application. These lessons included citizenship, drill, inspections, guard duty, cleaning their quarters, military customs and the vaguely defined troop information program. ${ }^{130}$ An evaluation grows even worse when noted that in the 1940's Army, physical training was generally understood, and occasionally explicitly designated as consisting largely of athletic games. ${ }^{131}$ The basic training curriculum was therefore significantly skewed towards activities meant to instill discipline and traditional ideals of American masculinity and citizenship rather than combat skills.

Additionally, while important combat skills appeared on the schedule, they often lacked a grounding in actual practice. ${ }^{132}$ Later surveys revealed that soldiers often did not receive proper instruction on basic techniques. For example, some men evidently left basic training having never fired a rifle. ${ }^{133}$ Other important skills were left out of training or not given enough focus. For instance, recruits received no specific training on night combat. Instead, instructors conducted eight hours of any normally scheduled training after dark. ${ }^{134}$ In perhaps the most

129 "The Basic Training Guide" (Military Services Publishing Company, 1948), 302-3, U408.3 .B372 1948, U.S. Army Heritage and Education Center.

130 "The Basic Training Guide," 303.

${ }^{131}$ Hanson, Combat Ready?, 43; "Basic Military Training: A Comprehensive Manual of Military Training" (Military Services Publishing Company, 1943), U408.3 .B37 1943, U.S. Army Heritage and Education Center.

${ }^{132}$ Pash, In the Shadow of the Greatest Generation, 63-64.

133 Arthur Drucker, Kenneth Bradt, and David Yaukey, "Strengths and Deficiencies of Precombat Training as Reported by Infantrymen in Korea" (Adjutant-General's Office. Personnel Research Section, 1952), 10, DS921.5.P4 D782 1952, U.S. Army Heritage and Education Center.

134 “The Basic Training Guide," 1948, 302-3. 
glaring omission, recruits received no instruction as to their rights and responsibilities regarding surrender and behavior as POW. ${ }^{135}$ These oversights had significant repercussions during the Korean War.

The basic training for officers had similar deficiencies. Unlike enlisted men, officers received no basic course at specialized camps. Rather, their commissioning source, either the Military Academy or ROTC, taught them basic skills while they received their college degrees. This often poor and inconsistent training focused almost entirely on drill, administration and other non-combat skills. This was especially a problem in the more civilian and academically inclined ROTC. ${ }^{136}$ After graduation, the system immediately tossed the new officers straight to frontline units for "on the job training." 137 As a result, a new officer arriving at an operational unit before Korea likely had less schooling in warfare than those he led.

In addition to problems with the curriculum, issues with organization negatively impacted training especially how the Army organized its training cadres. Unlike the Marine Corps, where each platoon had a single, highly trained Drill Instructor responsible for its entire training, the Army took a more distributed approach. ${ }^{138}$ Experts taught technical classes such as chemical warfare and weapon assembly, while a separate drill cadre handled the 99 hours of drill, inspections, and other relatively inane aspects of basic training. ${ }^{139}$

These drill cadres were heavily overworked and many capable soldiers tried to avoid the position. The Army, not believing that cadre needed to be particularly skilled, filled the gaps

\footnotetext{
${ }^{135}$ R.B. Lewis, "Prisoner of War Survival" (Research and Development Board. Working Group on Human Behavior under Conditions of Military Service, 1951), 4, U393.5 .U55 Appx.112, U.S. Army Heritage and Education Center. ${ }^{136}$ Neiberg, Making Citizen Soldiers, 30-31; Linn, Elvis's Army, 25-27.

${ }^{137}$ Jaques, "United States Army Infantry Training Program Effectiveness During the Korean War," 36-37.

${ }^{138}$ Howard Uphoff, "Indoctrination and Basic Training" (Research and Development Board. Working Group on Human Behavior under Conditions of Military Service, 1951), 9, U393.5 .U55 Appx.171, U.S. Army Heritage and Education Center.

${ }^{139}$ Linn, Elvis's Army: Cold War GIs and the Atomic Battlefield, 198.
} 
with whatever men were readily available. ${ }^{140}$ As a result, drill cadres often included minimally skilled individuals without specialized instructor training. ${ }^{141}$ With some exceptions, they often only bullied their charges, providing little helpful training and causing significant drops in morale among new recruits. ${ }^{142}$ Because the Army did not regard conducting non-technical training as requiring expertise, its basic training program quickly disillusioned new soldiers.

The organization of Army basic training was also deficient regarding its time table. In theory, it sought to train the most amount of personnel in the shortest time, making the overall personnel system more efficient for a rapid build-up in an emergency. ${ }^{143}$ Nonetheless, Army basic training before Korea took a fairly relaxed pace as template schedules from 1948 used the civilian-standard 40-hour work week. ${ }^{144}$ This was not an intensive program, especially when contrasted to a standard WWII schedule with four more hours per week while being five weeks longer. ${ }^{145}$ Soldiers even had the opportunity to leave post on the weekends to see shows and drink at local bars. ${ }^{146}$ In a time of apparent peace, the Army evidently chose to model itself on the civilian world to make life easier for its recruits and to attract volunteers.

By 1949, however, the Army realized its relaxed schedule produced unprepared soldiers. With complaints from units mounting, the Army tried switching to a 14-week basic training schedule simultaneously with the Selective Service restarting. Utter chaos followed in the

\footnotetext{
${ }^{140}$ Linn, 198-200.

${ }^{141}$ J.R. Berkshire and T.H. Harrell, "General Principles of Effective Training and Training Organization” (Research and Development Board. Working Group on Human Behavior under Conditions of Military Service, 1951), 13-15, U393.5 .U55 Appx.200, U.S. Army Heritage and Education Center.

${ }^{142}$ Linn, Elvis's Army, 42, 65, 198-200; “New Soldiers' Attitudes -- After Six Weeks of Training 1, Trends in Adjustment and Orientation," 3.

${ }^{143}$ Berkshire and Harrell, "General Principles of Effective Training and Training Organization," 3.

144 "The Basic Training Guide," 301-303

145 "Basic Military Training: A Comprehensive Manual of Military Training," 172-173

${ }^{146}$ DeHaan to Page, April 26, 1950, DeHaan Correspondence.
} 
training camps as overburdened staff struggled to sort out each recruit's training requirements.

As a result, many recruits received even less training than before. ${ }^{147}$

To make the debacle worse, the new program had few improvements over the 8-week one. The proportion of time spent on each subject remained more or less the same between the two programs without substantial additions to the curriculum. ${ }^{148}$ Later studies concluded that the longer schedule resulted in no significant improvement in combat performance. ${ }^{149}$ Despite recognition of the deficiencies of its training system, the Army's leaders failed to make any substantial reforms prior to the breakout of the Korean War.

Unfortunately, Army training in the late 1940's, had a poor curriculum and dubious organization. Further mediocrity arose from its terrible execution. While bad on paper, basic training was worse in practice. Although training theoretically relied on realistic practical application, official publications often reduced it to simple checklists and question and answer guides. ${ }^{150}$ This probably limited what most instructors could accomplish given the poor qualification of many. ${ }^{151}$ Brian Linn, quoting the results of an Army investigation, summarized the situation well. "The instructors were both quantitatively and qualitatively inadequate and most training 'poorly planned, insufficiently executed, and hopelessly obsolete.",152

The effects of this severely dysfunctional basic training program were disastrous. Later studies indicated that, rather than inspiring new recruits, basic training quickly disillusioned

\footnotetext{
${ }^{147}$ Linn, Elvis's Army, 42-43.

${ }^{148}$ Hanson, Combat Ready?, 27; "The Basic Training Guide," 301-3.

${ }^{149}$ Harry Bornstein et al., "Measures of Combat Performance in Korea. Volume 3: Comparison of Measures for Men Trained Under Peacetime and Mobilization Basic Training Programs" (Adjutant-General's Office. Personnel Research Section, 1952), 5-6, DS921.5.P4 M42 1952, U.S. Army Heritage and Education Center.

150 "The Basic Training Guide," 1948.

${ }^{151}$ Berkshire and Harrell, "General Principles of Effective Training and Training Organization," 14.

${ }^{152}$ Linn, Elvis's Army, 42.
} 
many. ${ }^{153}$ Even worse, many emerged from basic believing that the Army's leadership lacked competence and expertise. ${ }^{154}$ Given the existing state of officer training, and the exodus of experienced combat leaders from the service after WWII, this appraisal likely had merit. Finally, and perhaps most damning, few soldiers believes themselves ready for combat. ${ }^{155}$ This was particularly ominous as at least one cultural study declared that the first prerequisite for an American soldier to fight well was that "his competence - concerning training and equipment - is superior to that of his enemy and can be relied upon under conditions of stress." ${ }^{\prime 156}$

The impact of the Army's failure to conduct effective basic training cannot be understated. Training camps churned out new troops that were almost more liabilities than assets. A 1947 report from Eighth Army, the U.S. frontline garrison in Japan, proved enlightening. Replacement troops received between 1946 and 1947 "were neither basically trained nor had sufficient specialized training to be of immediate use to units. These replacements thus became a temporary burden on units which had been struggling along with the minimum number of personnel." ${ }^{157}$ The Army's process for creating soldiers clearly failed. Frontline combat units received men who were little more than civilians. Unfortunately for these units' commanders, the failures of basic training proved to be only one of many obstacles in preparing their men for war. The issues with unit level training differed from basic training owing to the former's less centralized nature. Individual units were responsible for both teaching their new soldiers

\footnotetext{
${ }^{153}$ Mundy, American Militarism and Anti-Militarism in Popular Media 1945-1970, 36; "New Soldiers' Attitudes -After Six Weeks of Training 1, Trends in Adjustment and Orientation," 3.

${ }^{154}$ Linn, Elvis's Army, 199; "New Soldiers' Attitudes -- after Six Weeks of Training. 2. Reactions to Training” (Armed Forces Information and Education Division. Attitude Research Branch, n.d.), 14, U22.3 .N493 1951, U.S. Army Heritage and Education Center.

155 "New Soldiers' Attitudes -- after Six Weeks of Training. 2. Reactions to Training," ii-iii.

${ }^{156}$ Clyde Kluckhohn, "American Culture and Military Life" (Research and Development Board. Working Group on Human Behavior under Conditions of Military Service, 1951), 60, U393.5 .U55 Appx.106, U.S. Army Heritage and Education Center.

157 8th Army Headquarters, "Summary of Personnel Problems from Activation to Occupation: Yokohama, Japan, 1 February 1947," 27-28.
} 
advanced skills and sustaining their own readiness. ${ }^{158}$ The quality of this training varied considerably depending on the attitudes and competence of local leadership. An analysis of unit level training focuses primarily on Eighth Army since it was the primary force committed to Korea during the early stages of the war. Admittedly, Army-wide trends still significantly affected the training of smaller units.

Problems started early on because of the poor quality of newly minted soldiers who often arrived with limited skills, thus severely disrupting local training curriculums. Usually, local units spent significant time brining these men up to speed on basic aspects of soldiering. Furthermore, high turnover rates attributable to the turbulent personnel system and short enlistment periods ensured almost continuous repetition of this process. ${ }^{159}$ This restricted larger units from training as a group because subordinate formations constantly had to retrain new arrivals. ${ }^{160}$ When units finally made progress training one group, rapid turnover ensured they soon had to train another group similarly lacking basic skill. ${ }^{161}$

Aside from personnel problems, the Army had widespread issues with equipment that plagued Eighth Army training programs. Just as civilian priorities had influenced personnel selection and basic training, it also impacted equipment procurement, largely bringing it to a screeching halt to save costs. By 1950, the Eighth Army lacked new equipment and what it did have was mostly standard infantry kit. There were severe shortages of all types of heavy weapons from flamethrowers to mortars. This naturally precluded the men assigned such weapons from practicing with them. ${ }^{162}$

\footnotetext{
${ }^{158}$ Hanson, Combat Ready? The Eight U.S Army on the Eve of the Korean War, 27.

${ }^{159}$ Hanson, Combat Ready?, 20-27.

${ }^{160}$ Linn, Elvis's Army, 41.

${ }^{161}$ Hanson, Combat Ready?, 66.

${ }^{162}$ Hanson, 37-41.
} 
Perhaps most significant was the dire shortage of tanks. In 1946, a committee of the Army's top brass stripped infantry regiments of their dedicated anti-tank companies and their towed AT cannons and replaced them with organic tank battalions directly under the control of the regimental commander. This made the new T-26 Pershing medium tank the primary anti-tank weapon of the infantry regiment. ${ }^{163}$ Despite this change in doctrine, neither Congress nor the Army made any provision to provide these weapons to Eighth Army. By 1950, there was not a single T-26 in all of Japan and only a handful of WWII vintage M-24 light tanks. ${ }^{164}$ The soldiers of Eighth Army remained unable to practice the vital anti-tank tactics the Army expected right up until they faced the North Korean T-34-85s.

In addition to these global factors, two issues unique to the Eighth Army's operating environment impacted its ability to conduct training. First, Japan's geography afforded few training areas suitable for large scale maneuvers or live fire. Some regimental training areas were so restrictive that only one squad could engage in live fire at a time. ${ }^{165}$ Second, the Eighth Army's primary mission revolved around serving as an army of occupation. Up until released from this duty in 1949, Eighth Army troops were simply too busy to conduct serious combat training. Whether this resulted from the troops being absorbed in their mission or carousing remains a question that splits the research. ${ }^{166}$ Because of these myriad factors, the soldiers of the Eighth Army often lacked the opportunity to experience realistic training or even practice basic tactical skills.

\footnotetext{
163 "Report of Special Committee on Organization of The Infantry Division" (Fort Benning, GA: The Infantry Conference, June 1946), 4, Published by BiblioGov as part of "Infantry Conference Report of Committee on Organization: June 1946, Part 3."

${ }^{164}$ Hanson, Combat Ready?, 14.

${ }^{165}$ Hanson, 52.

${ }^{166}$ Fehrenbach, This Kind of War, 66; Hanson, Combat Ready?,14-15; Linn, Elvis's Army, 33-35. For further reading on the conduct of U.S. occupation troops in Japan, see The Good Occupation by Susan Carruthers
} 
Army wide issues of organization and execution likely rendered the little training accomplished by Eighth Army prior to 1949 ineffective. It was unlikely that merely having more training opportunities could have changed this trend. A good case study regarding widespread flaws in the Army's unit training is Field Training Exercise (FTX) 50, codenamed Operation Rainbow. Conducted in September 1950, FTX-50 was the culmination of European Command's annual training cycle. Conducted in the most important theater of operations for the U.S. Army and prepared in the midst of large-scale training reforms during 1949, one can reasonably consider FTX-50 an example of the best training practices of the pre-Korean War Army. ${ }^{167}$

Unfortunately, this best-case scenario demonstrated numerous shortcomings with the Army's large-scale maneuvers. From the beginning, planners failed to create sufficiently detailed schemes of maneuver for friendly and aggressor forces, resulting in a severe breakdown in the realism of the exercise. According to one after action report, "umpires and commanders of actual aggressor units [were unable] to present consistent, logical, theoretical and actual problems to US battalions and subordinate commanders." ${ }^{.168}$ Similarly, although Army doctrine stipulated that a three to one ratio of friendly forces to aggressor forces was necessary for realistic training, FTX-50 only provided enough aggressors to achieve a seven to one ratio. ${ }^{169}$

In addition to poor organization stripping the exercise of realism, execution by participating units also failed. Of particular note, rear service units rarely took the exercise seriously. For example, the exercise's scenario gave the J-4 logistics section little to do. ${ }^{170}$ Other rear area troops completely ignored scenarios involving infiltration by enemy troops. The ground

\footnotetext{
${ }^{167}$ Linn, Elvis's Army, 44-45; United States Army European Command Historical Division, "Final Report, Joint Field Training Exercise (Exercise Rainbow), 11-18 September 1950.”

168 United States Army European Command Historical Division, "Final Report, Joint Field Training Exercise (Exercise Rainbow), 11-18 September 1950," 86.

${ }^{169}$ United States Army European Command Historical Division, 95.

${ }^{170}$ United States Army European Command Historical Division, 71.
} 
forces commander for the exercise noted that "service troops in rear areas had little or no concept of what action to take when attacked by small aggressor detachments. It appeared that the attitude of such troops was that it was not their job to fight or escape."171

These evaluations highlight the limited positive effects of such exercises. Overall, they tended to be highly artificial as most troops spent their time wandering about in confusion. ${ }^{172}$ Indeed, in his remarks near the end of the exercise report, General Thomas T. Handy specifically underscored many soldiers spent Exercise Rainbow mostly driving around in trucks rather than getting much-needed experience in cross-country movement and navigation. ${ }^{173}$ As such, it appears most Army field training had limited benefits.

However, Exercise Rainbow revealed the Army's poor state of training ensuring one positive outcome. Beyond the unsoldierly attitudes of rear service troops and a dependance on motor-transport, it uncovered serious deficiencies in aerial reconnaissance, night operations, soldier morale, and the handling of communications during a simulated retreat. ${ }^{174}$ All these reappeared during key battles in the Korean War. Unfortunately, by the time this exercise unfolded, U.S. troops already had entered Korea.

That being said, there's evidence to suggest that the Army was already aware of these problems but failed to address them. Brigadier General Thomas Darcy, the USAF officer commanding the $2 \mathrm{~d}$ Air Division which supported FTX-50, leveled substantial criticisms at the Army. In his debriefing with the exercise staff, Darcy employed a variety of enigmatic metaphors to suggest that the Army willfully ignored warning signs of needed changes to its

\footnotetext{
${ }^{171}$ United States Army European Command Historical Division, 81.

${ }^{172}$ Linn, Elvis's Army: Cold War GIs and the Atomic Battlefield, 43. Linn's description of Exercise Miki in the Pacific in 1949 is very similar to my own findings regarding Exercise Rainbow.

${ }^{173}$ United States Army European Command Historical Division, "Final Report, Joint Field Training Exercise (Exercise Rainbow), 11-18 September 1950," 113.

${ }^{174}$ United States Army European Command Historical Division, 67-68, 70, 81-82, 101.
} 
training. He claimed FTX-50 highlighted the same problems from the previous two annual exercises and that the Army failed to remedy them.

The remarks made at the meetings which followed those exercises are as applicable today as they were on the day they were made.... Let us, in the time between maneuvers, do something positive and fruitful about the thing we have already found out so that our progress can be measured successively from ever advancing baselines - not from the same one each time. ${ }^{175}$

High ranking Army officers involved, in the exercise characterized it as entirely validating the Army's doctrine and training, seemingly confirming Darcy's view of his counterparts. ${ }^{176}$ Thankfully, not all senior Army officers blindly accepted their situation. Lieutenant General Walton Walker, commander of Eighth Army, realized that his forces woefully lacked preparation and launched a major training initiative in mid-1949. ${ }^{177}$ However, it was too little, too late. Walker could do little to fix the problems with recruitment and basic training, which hampered unit training and, although he did not know it, he had very little time. ${ }^{178}$ War broke out on the Korean peninsula on June 25th 1950, just before Eighth Army had its first regimental maneuvers since the end of WWII. ${ }^{179}$

U.S. Army training between WWII and the Korean War was certainly not good. Effective basic training was simply non-existent. Simultaneously, a lack of equipment, facilities, personnel, and most of all, effective leadership capable of conducting useful training severely hampered unit level preparedness. ${ }^{180}$ Additionally, many valuable training courses and exercises

\footnotetext{
${ }^{175}$ United States Army European Command Historical Division, 98. Underlining in original.

${ }^{176}$ United States Army European Command Historical Division, 80.

${ }^{177}$ Hanson, Combat Ready? The Eight U.S Army on the Eve of the Korean War, 16-20.

${ }^{178}$ Hanson, 34-45.

${ }^{179}$ Linn, Elvis's Army: Cold War GIs and the Atomic Battlefield, 44-45.

180 Jaques, “United States Army Infantry Training Program Effectiveness During the Korean War,” 30-34, 93-94.
} 
developed in WWII ended due to cost and safety concerns. ${ }^{181}$ All the while, senior Army leaders often failed to recognize these deficiencies or take corrective action. ${ }^{182}$

Some bright spots existed. General Walker's training push in 1949 empowered capable junior leaders to significantly improve the readiness of several units in Eighth Army. ${ }^{183}$ This progress depended on vigorous execution by local leaders however, resulting in very uneven training quality between different units. ${ }^{184}$ Even with these late reforms then, the overall state of training for frontline infantry units in Eighth Army never met acceptable standards.

On the eve of the Korean War, the U.S. Army lacked a claim to be the world's premier fighting force. Its soldiers were a loose collection of the unwilling and uneducated, and there were not enough of them. They were barely trained citizens, shunted to the frontiers to play soldier for a few months. They lacked equipment, motivation, good leadership and they were entirely unprepared for modern warfare.

Clearly, the pre-Korean War Army was the product of a society unprepared to fight a ground war anywhere, least of all in a remote region protecting foreigners. Serious deficiencies in recruitment, basic training, and unit exercises demonstrate that fielding a large, capable ground force was simply not an American priority. To ascertain what mattered, the annex to Eighth Army's 1947 personnel report, written for the House Military Affairs Committee, provides insights. The report quickly glossed over an impending manpower crisis to tell the

\footnotetext{
181 Jaques, 55-56, 87-89.

182 United States Army European Command Historical Division, "Final Report, Joint Field Training Exercise (Exercise Rainbow), 11-18 September 1950," 80-98.

${ }^{183}$ Hanson, Combat Ready?, 25-27, 32-33, 65.

184 Jaques, 39, 93.
} 
congressmen what presumably concerned them most: church attendance statistics and aggregate PX sales. ${ }^{185}$ Public morals and money mattered, not the possibility of a ground war.

185 8th Army Headquarters, "Summary of Personnel Problems from Activation to Occupation: Yokohama, Japan, 1 February 1947," 48-50. The report proudly boasts that, of a total force of 86,500 men, 93,000 men attended 2,800 church services over the course of a month. 


\section{$4 \quad$ Mud and Blood}

On July $5^{\text {th }} 1950$, as Task Force Smith moved forward to buy time, the $34^{\text {th }}$ Infantry regiment of the $24^{\text {th }}$ Infantry Division (ID). took up defensive positions near the villages of Pyongtaek and Ansong. A highway connected them and an estuary and mountains anchored their position. This area represented the best blocking position on the western half of the Korean Peninsula south of Seoul. 24 $4^{\text {th }}$ ID commander Major General William Dean considered holding the position to be critical. ${ }^{186}$ Understrength and lacking heavy weapons, there was little chance that the $34^{\text {th }}$ Infantry could hold these positions indefinitely. ${ }^{187}$ However, every hour it delayed the KPA, more reinforcements could arrive. The $34^{\text {th }}$ needed to fight long as possible to slow the enemy advance. Instead, it conducted one of the more disgraceful retreats in U.S. military history.

Sitting in their rain filled foxholes north of Pyongtaek, the soldiers of the $1^{\text {st }}$ Battalion were uncomfortable and grouchy. They also lacked information about the combat situation. Few knew Task Force Smith's fate and still believed it was a minor police action rather than a fullscale war. ${ }^{188}$ Unsurprisingly then, they reacted poorly when North Korean units attacked them. Despite admonishments from their WWII experienced sergeants, almost half of them never fired their weapons, some dazed by the sudden shock of combat. Others had reassembled their rifles incorrectly or failed to clean them, causing malfunctions that poorly trained soldiers could not fix. ${ }^{189}$ Fumbling in their first taste of combat, the soldiers of the $34^{\text {th }}$ performed poorly. The battalion quickly became unglued. their attempt to withdraw quickly became a rout as the men

\footnotetext{
186 Appleman, South to The Naktong, North to The Yalu, 77-79.

${ }^{187}$ Fehrenbach, This Kind of War: The Classic Korean War History, 73.

${ }^{188}$ Russell Gugeler, Combat Actions in Korea, Army Historical Series (Washington, D.C.: Center of Military History, U.S. Army, 2000), 4.

${ }^{189}$ Gugeler, 8-11.
} 
panicked and fled for their lives. They tossed aside ammunition, helmets, and weapons as they ran. Despite partially restoring order a mile or so south, the shattered companies of $1^{\text {st }}$ Battalion immediately continued their retreat 15 miles south to Chonan. ${ }^{190}$

The march to Chonan was a disorganized mess. There were no communications between the different units of the battalion, with each company making its own way to safety. They left behind or deliberately discarded weapons and equipment which littered the muddy road. By the time they reached Chonan, the soldiers of $1^{\text {st }}$ Battalion were strung out across several miles of road and completely exhausted. ${ }^{191}$ Had the enemy bothered to mount a vigorous pursuit, they could have easily slaughtered the demoralized and disorganized Americans. Resisting weakly, the $34^{\text {th }}$ entirely failed to hold its critical defensive positions.

The conduct of the $34^{\text {th }}$ Infantry reflects the U.S. Army's weaknesses in 1950. It had mostly undertrained, undereducated and undermotivated conscripts on short-term contracts and it rarely resembled the lean, highly educated, and technically inclined organization planners thought necessary for modern combat. Rather, it reflected decidedly civilian purposes, resembling a social engineering project, an economic engine, and, in occupied Japan and Germany, a police force. T.R. Fehrenbach justifiably called it "exactly the kind of pampered, undisciplined, egalitarian army their society had long desired and had at last achieved."192

When this Army hastily entered the Korean War, the poor state of its training became apparent to the world. However, whether infantry proponents admitted it or not, the outcome of modern war was not solely dependent on the man in the foxhole. Poor training was only one, and not necessarily the most important factor causing the U.S. Army's early defeats in Korea. Its

\footnotetext{
${ }^{190}$ Fehrenbach, This Kind of War: The Classic Korean War History, 76; Gugeler, Combat Actions in Korea, 10.

${ }^{191}$ Gugeler, Combat Actions in Korea, 13-14.

${ }^{192}$ Fehrenbach, This Kind of War: The Classic Korean War History, 84.
} 
severe lack of serviceable equipment, serious mistakes by senior leaders, and the questionable priorities of civilian authorities contributed to poor performance. Additionally, one must consider the considerable skill and determination of the enemy. The Korean War reminds us that not all totalitarian regimes have fools and maniacs as leaders.

None of this, however, was apparent when, on June 25, 1950, the North Korean People's Army (KPA) opened the war with a hammer-blow. An unprepared Republic of Korea (ROK) faced them despite months of skirmishing preceding this offensive. U.S. political leaders ensured that military advisors prepared the ROK military to deal only with a domestic insurgency and light border actions, not full-scale armored warfare. ${ }^{193}$ In contrast, Kim Il Sung, with the assistance of Soviet advisors, had prepared his KPA for this offensive for quite some time. ${ }^{194}$ The Communists were well-prepared, coordinated, and devastatingly effective. Spearheaded by the tanks of the fearsome $105^{\text {th }}$ armored brigade, the KPA drove back the ROKs despite desperate resistance including the deployment of suicide bombers. ${ }^{195}$ In barely three days of fighting the KPA effectively destroyed the ROK Army. ${ }^{196}$

Almost immediately, the U.S. military came to its ally's aid. The day after the initial assault, the Far East Air Forces (FEAF) seized control of the air and began striking KPA forces south of the parallel. ${ }^{197}$ A few days later, on June 30, Lieutenant Colonel Charles Smith of the $1^{\text {st }}$ Battalion, $21^{\text {st }}$ Infantry Regiment, $24^{\text {th }}$ Infantry Division (ID) received orders to lead the first American ground troop into the battle. ${ }^{198}$ Unfortunately, the U.S. Army was not in a good position to render aid. The Eighth Army was understrength and its divisions spread thinly across

\footnotetext{
${ }^{193}$ Fehrenbach, 7, 32.

${ }^{194}$ Sergei Goncharov, John Lewis, and Litai Xue, Uncertain Partners Stalin, Mao, and the Korean War (Stanford, CA: Stanford University Press, 1993), 133-36.

195 Fehrenbach, This Kind of War: The Classic Korean War History, 37-45.

196 Fehrenbach, 48-49.

197 Appleman, South to The Naktong, North to The Yalu, 51.

198 Appleman, 60.
} 
Japan. General Douglas MacArthur, Supreme Commander Allied Powers (SCAP) in Japan, commander-in chief Far East Command (FECOM), and newly appointed Commander-in-chief United Nations command (UNC), ordered General Dean's $24^{\text {th }}$ Division to move to Korea purely because it was stationed in Kyushu and therefore closest to Korea. ${ }^{199}$ But Dean's forces were in six separate ports, and he could not wait to move his entire division to Korea at once if he hoped to save the reeling ROKs. ${ }^{200}$ The $24^{\text {th }}$ joined the battle piece by piece and Smith, who commanded troops at Pearl Harbor on Dec $7^{\text {th }}$ 1941, once again was at America's vanguard.

Smith departed Japan via airlift with about half of his $1^{\text {st }}$ Battalion, reinforced with men pulled from other units, on July $1^{\text {st. }}$ Smith's orders were to head north from Pusan and meet in with Major General John Church, the head of the Korean Military Advisory Group (KMAG) and the senior officer on the ground in Korea. From there he was to "block the main road as far north as possible. ${ }^{" 201}$ When Smith met with Church in Taejon on July 2, Church instructed him to move north and support ROK forces near Pyeongtaek and Osan. "All we need is some men up there who won't run when they see tanks," Church optimistically told Smith. ${ }^{202}$

Three days later, Smith's motley task force, now bolstered with elements from Lieutenant Colonel Miller Perry's 52 ${ }^{\text {nd }}$ Field Artillery Battalion, held the high ground north of Osan. ${ }^{203}$ The men were confident. Their commanders told them that the KPA were poor fighters and that this "police action" would end quickly. The men, expecting to return to Japan shortly, had left their belongings in their barracks. No one told them to expect tanks even though Church explicitly informed Smith of the threat. ${ }^{204}$

\footnotetext{
199 Appleman, 49.

${ }^{200}$ Fehrenbach, This Kind of War: The Classic Korean War History, 65.

${ }^{201}$ Appleman, South to The Naktong, North to The Yalu, 60.

202 Appleman, 61.

${ }^{203}$ Fehrenbach, This Kind of War: The Classic Korean War History, 65-66.

${ }^{204}$ Tomedi, No Bugles, No Drums: An Oral History of the Korean War, 2-5.
} 
The soldiers soon forgot these rosy predictions when 34 T-34-85s leading two full regiments of KPA infantry appeared before them in a column six miles long. ${ }^{205}$ The Americans attacked, surprising the North Koreans with mortar, rifle, and machinegun fire. Despite taking heavy casualties, the North Koreans regrouped and counter-attacked. A fierce battle ensued as the KPA soldiers tried to flank the Americans while most of their tanks broke through the center and continued their way south. After several hours, the North Koreans seized the high-ground on both flanks while Smith's men ran low on ammunition. Facing an increasingly desperate situation, Smith finally withdrew. ${ }^{206}$

Up until this point in the battle, the soldiers of Task Force Smith fought hard and stood their ground. However, their inability to stop the enemy tanks and the realization that they faced a superior force severely shook them. Withdrawing under heavy fire, their discipline finally broke and the unit shattered. As individuals or in small groups, the Americans turned tail and made their way south. On July $6^{\text {th }}$ a headcount revealed that the Task Force suffered 150 total casualties out of 400 men. America's first battle in the Korean War was a complete defeat. ${ }^{207}$

Despite the unfortunate final result, however, the soldiers of Task Force Smith performed fairly well. Green, poorly equipped, without support, and heavily outnumbered, they held their ground for a total of 7 hours against battle hardened soldiers. Some scholars have estimated that their efforts delayed the North Korean advance by as much as five days. ${ }^{208}$

\footnotetext{
205 Appleman, South to The Naktong, North to The Yalu, 72.

${ }^{206}$ Heller and Stofft, America's First Battles 1776-1965, 280-81.

207 Appleman, South to The Naktong, North to The Yalu, 74-75.

208 Stanley Sandler, The Korean War: No Victors, No Vanquished (Lexington KY: University Press of Kentucky, 1999), 59; This estimate is disputed by Raymond M. Longabaugh who claims that the KPA was barely slowed down by the engagement, "Task Force Smith and the 24th Infantry Division in Korea, July 1950" (ARMY COMMAND AND GENERAL STAFF COLLEGE FORT LEAVENWORTH KS SCHOOL OF ADVANCED MILITARY STUDIES, May 22, 2014), 38, https://apps.dtic.mil/sti/citations/ADA612249.
} 
Unfortunately, the $34^{\text {th }}$ Infantry did not perform nearly as well. After their defeat, and with the Pyeongtaek line broken, General Dean lost his last best chance to stop the KPA advance. ${ }^{209}$ With neither enough troops or advantageous terrain to secure his flanks, the best Dean could do was delay the North Koreans in losing battles until the rest of $8^{\text {th }}$ Army could arrive. As more of Dean's troops became available, the battles escalated in intensity but generally followed the same pattern.

Typically, the Americans set up whatever units they could muster in long lines blocking major roadways. Already understrength and depleted by casualties, these "lines" were usually thin strings of isolated units along the hilltops. They also generally lacked backup from a reserve force. The North Koreans easily pierced these defenses with their armor while infantry flanked American positions, or infiltrated between their widely spaced units. When outmaneuvered, the Americans attempted to withdraw but often found the enemy already in blocking positions behind them. Cut off and under fire, the American units struggled to maintain discipline and unity as they retreated to friendly lines. They often failed. ${ }^{210}$

In this manner, the dispersed battalions and companies of $24^{\text {th }}$ ID played a deadly game of leapfrog with their opponents as they retreated towards the U.N. Headquarters in Taegu and the main port of Pusan. This Fabian campaign climaxed at the battle of Taejon on July 14th. There, for the first time, Dean gathered his entire division on a single defensive line along the Kum river just northwest of the transportation hub of Taejon. ${ }^{211}$ Dean's men also had for the first

\footnotetext{
${ }^{209}$ Fehrenbach, This Kind of War: The Classic Korean War History, 78.

${ }^{210}$ Norman Black, ed., Combat Veterans' Stories of the Korean War, vol. 1 (CreateSpace Independent Publishing, 2016.), 42-43; Appleman, South to The Naktong, North to The Yalu, 90-94, 101-08; Fehrenbach, This Kind of War: The Classic Korean War History, 80-91.

${ }^{211}$ Fehrenbach, This Kind of War: The Classic Korean War History, 88.
} 
time 3.5in bazookas capable of killing KPA tanks. ${ }^{212}$ However, these advantages could not overcome the division's enormous casualties and low morale. ${ }^{213}$

The ensuing battle quickly devolved into a chaotic brawl amidst the streets of Taejon and its surrounding hills. ${ }^{214}$ The 24th retreated once again in disorder with Dean presumed dead, last seen leading a bazooka team on the hunt for tanks. The Americans discovered over a year later that the North Koreans captured him. ${ }^{215}$ The $24^{\text {th }}$ Division itself was utterly spent as a fighting force. However, despite repeated defeats, the 24th bought crucial time for the rest of $8^{\text {th }}$ Army to arrive. $^{216}$

These early battles demonstrated the deficiencies of the American Army. Training was certainly a major issue. As the $34^{\text {th }}$ Infantry's first fight shows, many soldiers could not conduct simple maintenance on their weapons, something they should have learned in basic training. Furthermore, the responses of the men to combat indicate a lack of realistic unit level training. It took almost 15 minutes for the $1^{\text {st }}$ Battalion to get just half of its men shooting and many soldiers mistook incoming tank rounds for friendly mortars falling short. Finally, A Company's officers also made a mistake by positioning one of their platoons where it could not support the others. ${ }^{217}$ Effective training and realistic exercises conducted prior to the war might have eliminated such mistakes and shortcomings. Unfortunately, the 34ths previous commander led it so poorly that he was fired for incompetence shortly before the war. ${ }^{218}$ When Colonel Jay Loveless, took over the regiment, he found it short almost half its NCOs and severely lacking in

\footnotetext{
212 Sandler, The Korean War: No Victors, No Vanquished, 66.

${ }^{213}$ Fehrenbach, This Kind of War: The Classic Korean War History, 88; Appleman, South to The Naktong, North to The Yalu, 147.

${ }^{214}$ Appleman, South to The Naktong, North to The Yalu, xi.

215 Appleman, 176-77.

${ }^{216}$ Fehrenbach, This Kind of War: The Classic Korean War History, 95-100.

${ }^{217}$ Gugeler, Combat Actions in Korea, 8-10, 18.

${ }^{218}$ Heller and Stofft, America's First Battles 1776-1965, 272.
} 
serviceable weapons. ${ }^{219}$ Without experienced soldiers to teach combat skills or equipment to practice with, little realistic or helpful training likely occurred in the $34^{\text {th }}$.

In contrast, the performance of Task Force Smith proved that training at the unit level could at least partially overcome the deficiencies of basic training. Prior to the war, Smith's training reports were notably more optimistic than Loveless's and his men's conduct in battle reflected this. ${ }^{220}$ They performed admirably despite being in a similar, if not worse, situation to the $34^{\text {th }}$ Infantry. They fought until their ammunition ran dry and several exposed themselves to danger to fire bazooka rounds at the enemy tanks. They also deployed themselves in strong, mutually supportive positions. ${ }^{221}$ North Korean soldiers themselves regarded the engagement as a major battle. ${ }^{222}$ The soldiers of the $1^{\text {st }}$ Battalion $21^{\text {st }}$ Infantry who composed the bulk of the task force evidently had better preparation than their counterparts in the $34^{\text {th }}$. As a result, they did not break until they attempted to withdraw.

However, once they began their withdrawal, the unit quickly fell apart. In this case, a lack of familiarity may have contributed to their collapse. Before leaving Japan, Smith grabbed up every available man to fill holes in $1^{\text {st }}$ Battalion's roster, including Ray Mellin, a lab technician who had in Japan for ten days who became a field medic. ${ }^{223}$ Similarly, artilleryman Bob Fitzgerald of the $56^{\text {th }}$ Field Artillery suddenly was a machine gunner. ${ }^{224}$ Much of the unit then had not trained together or as infantry. Thus, the turbulent personnel situation in Eighth Army reduced Task Force Smith's cohesion and effectiveness before the battle even began.

\footnotetext{
${ }^{219}$ Hanson, Combat Ready? The Eight U.S Army on the Eve of the Korean War, 87.

220 Hanson, 88.

${ }^{221}$ Tomedi, No Bugles, No Drums: An Oral History of the Korean War, 10-11; Appleman, South to The Naktong, North to The Yalu, 69.

${ }^{222}$ Sandler, The Korean War: No Victors, No Vanquished, 74.

${ }^{223}$ Ray Mellin, Task Force Smith: One Day of Combat and Three Years of Prison, Oral History, October 24, 2016, https://www.westpointcoh.org/interviews/task-force-smith-one-day-of-combat-and-three-years-ofprison?fbclid=IwAR2GuWY7PiaR3ivCXFhKp6bYHAxC5LO6aKMbmHjyryy4SLUzJCAB4T6I33w. 224 Tomedi, No Bugles, No Drums: An Oral History of the Korean War, 10.
} 
However, at the time training should have done more than refine a soldier's technical skill. It also needed to develop a soldier's motivation and discipline. Most U.S. soldiers demonstrated little of the former. Many joined the Army expecting it to be a brief detour from their daily lives rather than a true calling and basic training did little to change this expectation. ${ }^{225}$ As Fehrenbach put it, "they had enlisted for every reason known to man except to fight." 226 The Army's recruitment tactics were at least partially responsible for encouraging this view. It was so desperate for recruits and reenlistments that it downplayed the very real possibility of combat both in advertisements and training. ${ }^{227}$

The unique character of the Korean War exacerbated the morale problems alongside issues of training and recruitment. Fighting a limited war far from home against a nebulous enemy, few common soldiers saw the point in their mission. ${ }^{228}$ As Colonel Dick Stevens of the $21^{\text {st }}$ Infantry noted, “The men and officers have no interest in a fight not even dignified by being called a war. It was a bitter fight in which many lives were lost, and we could see no profit in it." 229

In addition to the troop's motivation, their discipline was woefully inadequate. GIs failed to follow orders with alarming regularity. The men of the $34^{\text {th }}$ slowly answered the order to fire, and those that did were largely squad leaders or experienced NCOs. Almost half the men never fired at all. ${ }^{230}$ Several artillerymen from Task Force Smith also abandoned their guns during the first tank assault and only returned after their officers and NCOs manned the guns. ${ }^{231}$ The

\footnotetext{
225 Joseph DeHaan to Dorothy Page, June 11, 1950, Joseph DeHaan Korean War correspondence (2015.084.w.r), Center for American War Letters Archives, Chapman University, CA. (hereafter DeHaan Correspondence).

${ }^{226}$ Fehrenbach, This Kind of War: The Classic Korean War History, 102.

227 Brian Linn, Elvis's Army: Cold War GIs and the Atomic Battlefield (Cambridge, MA: Harvard University Press, 2016), 33; DeHaan to Page, May 12 1950, DeHaan Correspondence.

${ }^{228}$ Fehrenbach, This Kind of War: The Classic Korean War History, 59.

${ }^{229}$ Fehrenbach, 102.

${ }^{230}$ Heller and Stofft, America's First Battles 1776-1965, 284.

${ }^{231}$ Fehrenbach, This Kind of War: The Classic Korean War History, 69.
} 
challenges went beyond not firing their weapons. In Task Force Smith, recoilless rifleman Rob Roy refused direct orders to retrieve his $75 \mathrm{~mm}$ which had been knocked away by a tank shell exploding. ${ }^{232}$ Other men left behind valuable equipment such as machine guns in the retreat, despite their leaders' instructions to the contrary. ${ }^{233}$

The cause of this lack of discipline is a hotly debated issue. ${ }^{234}$ However, the evidence seems to support Fehrenbach's assertion that post-WWII relaxation of discipline in the Army undermined the authority of officers and NCOs. ${ }^{235}$ Once the Korean War began, senior officers throughout the $24^{\text {th }}$ ID quickly realized that their men would not follow orders from mere sergeants and lieutenants. Instead, they had to take personal charge of combat, causing significant casualties among the top brass. ${ }^{236}$ Thus, in terms of technical skill, motivation, and discipline, the Army's training programs left many GIs unprepared for combat.

That being said, training was not solely the reason why Task Force Smith and the $34^{\text {th }}$ Infantry became unglued in the retreat. Instead, demoralization occurred for two additional reasons which generated panic among the troops: ineffective equipment and failures to communicate.

In terms of equipment, GIs lacked effective weapons against the KPA tanks. To counter an armored assault the soldiers of Task Force Smith had only six obsolete 2.36-inch bazookas; two $75 \mathrm{~mm}$ recoilless rifles minus their armor piercing ammunition; and six 105mm highexplosive anti-tank (HEAT) artillery shells, one third of Eighth Army's entire supply. ${ }^{237}$ As a result, Task Force Smith failed to stop the 30 North Korean tanks that attacked them even though

\footnotetext{
232 Tomedi, No Bugles, No Drums: An Oral History of the Korean War, 6.

233 Tomedi, 11.

${ }^{234}$ Linn, Elvis's Army: Cold War GIs and the Atomic Battlefield, 35.

${ }^{235}$ Fehrenbach, This Kind of War: The Classic Korean War History, 23; DeHaan to Page, June 11, 1950, DeHaan Correspondence; Tomedi, No Bugles, No Drums: An Oral History of the Korean War, 11,26.

${ }^{236}$ Fehrenbach, This Kind of War: The Classic Korean War History, 85.

${ }^{237}$ Fehrenbach, 66.
} 
they lacked infantry support; a mistake that left them vulnerable. The Americans opened fire with shots from the bazookas and $75 \mathrm{mms}$, but to little effect against the old but sturdy T-34s. The $105 \mathrm{~mm}$ howitzers from Perry's artillery disabled two tanks, but once they depleted their HEAT shells, their shots splashed harmlessly off the enemy armor. The Korean tanks pushed contemptuously through the roadblock, destroying vehicles and cutting communication wire. ${ }^{238}$ Multiple accounts of the battle describe how the tanks' impunity crippled the soldier's resolve. ${ }^{239}$ Bob Fitzgerald recalled his sensation after seeing a bazooka round bounce off a tank. "The hair went up on my neck. I thought, what the hell do we do now?"240

In addition to ineffective anti-tank weapons, the soldiers also lacked useful signals equipment. After KPA tanks cut the telephone wire between Smith's Infantry and Perry's artillery, they discovered that their radios did not work. As a result, Smith could not call-in artillery to attack the KPA infantry or defend against enemy flanking movements. ${ }^{241}$ With individual elements unable to communicate, Task Force Smith ceased fighting as a unified team against determined, well trained, and disciplined enemies, many with experience from fighting the Japanese in WWII. They could not make use of the combined arms firepower so necessary to success on the modern battlefield.

It was communications failure of another type, however, that proved a more damaging issue for both Task Force Smith and the $34^{\text {th }}$ Infantry. Evidence suggests that, in both engagements the chain of command's failure to disseminate critical information contributed to the breakdown of discipline. As military historian and military analyst S.L.A. Marshall found,

\footnotetext{
${ }^{238}$ Heller and Stofft, America's First Battles 1776-1965, 278-80.

${ }^{239}$ Tomedi, No Bugles, No Drums: An Oral History of the Korean War, 5; Black, Combat Veterans' Stories of the Korean War, vol 1:6-8.

${ }^{240}$ Tomedi, No Bugles, No Drums: An Oral History of the Korean War, 11.

${ }^{241}$ Heller and Stofft, America's First Battles 1776-1965, 280.
} 
instances of battlefield panic usually occur because soldiers are ignorant of the actions and purposes of others. He emphasized: "that was the common denominator, that the trouble began because somebody was thoughtless, somebody failed to tell other men what he was doing...It was not the sudden motion which itself did the damage but the fact that the others present were not kept informed. ${ }^{242}$ Importantly, Marshall recognized that preventing and controlling panics was not something achievable through training alone. Rather, the key factors were the unit's familiarity with each other and the talent and authority of field leaders. ${ }^{243}$

The battle at Osan is a perfect example of such a panic. The official history of the battle claims that Smith attempted to direct a carefully coordinated withdrawal, with B and C companies leapfrogging each other towards Osan, but the men broke due to enemy pressure. ${ }^{244}$ Oral histories from enlisted men, however, explicitly claim that no prearranged plan of withdrawal or rally point existed. Instead, the only instructions the soldiers received was a man on a hill calling out "every man for himself" or a runner shouting to retreat. Taking these instructions to heart, the men fled in disorder. ${ }^{245}$ Taken together with the fact that Smith's men did not know of the presence of tanks even when he did, these discrepancies indicate that critical information never reached his men, leading them to panic in their uncertainty.

The accounts of two platoon leaders from C company, $1^{\text {st }}$ Lieutenants Phillip Day Jr. and William Wyrick, reveal the extent of the issue. Neither officer knew about the presence of tanks, but the two had very different experiences of the retreat. Wyrick recalled Smith personally ordering him and another platoon leader to withdraw to another ridge and cover the battalion's

\footnotetext{
${ }^{242}$ S.L.A. Marshall, Men Against Fire: The Problem of Battle Command (Norman OK: University of Oklahoma Press, 2000), 145-46.

${ }^{243}$ Marshall, 147-50.

${ }^{244}$ Appleman, South to The Naktong, North to The Yalu, 74-75; Fehrenbach, This Kind of War: The Classic Korean War History, 70-71.

${ }^{245}$ Tomedi, No Bugles, No Drums: An Oral History of the Korean War, 6, 11; Black, Combat Veterans' Stories of the Korean War, vol 1:8.
} 
retreat. Wyrick then ordered his sergeants to bring the platoon and its equipment to the new position after he reconnoitered the area. For unknown reasons, his men never joined him at the rendezvous point but instead retreated with the main body. ${ }^{246}$

Meanwhile, Day, who was also the company executive officer, received the order to retreat from his company commander Captain Richard Dashner when KPA troops suddenly appeared behind them. Dashner told him they would leapfrog by platoons. When he moved his platoon out, machinegun fire shredded the unit which quickly disintegrated along with the rest of the task force. Both Wyrick and Day had little idea of where to go after the unfortunate withdrawal besides south. ${ }^{247}$

These accounts clearly show how the chain of command failed to convey crucial information and important intelligence apparently never reached lower than company level. Meanwhile, no consistency existed in delivering or receiving orders. At first glance, the official narrative and the accounts of junior officers indicate a fairly organized and controlled process. However, two platoon leaders in the same company apparently received different orders to withdraw, indicating a certain level of confusion among the officers. ${ }^{248}$ In fact, at least one platoon never received orders to withdraw at all. ${ }^{249}$ Additionally, the disappearance of Wyrick's platoon and the accounts of junior enlisted men indicated that runners and NCOs failed to deliver orders from the officers accurately. ${ }^{250}$ At multiple levels then, the leadership of Task Force Smith failed to convey to their soldiers essential information about how, where, and why to fall back.

\footnotetext{
246 Donald Knox, The Korean War: An Oral History (San Diego, CA: Harcourt Brace Jovanovich, 1985), 15-25.

${ }^{247}$ Knox, 21-27.

${ }^{248}$ Smith ordered Wyrick and another platoon leader to withdraw and cover the Battalion retreat while Dashner ordered $\mathrm{C}$ company to withdraw leapfrogging by platoons. If Dashner was unaware of Smith's orders to Wyrick and ordered withdrawal by platoons while Wyrick was conducting his reconnaissance, this would explain why Wyrick's platoon failed to rendezvous with him on the ridge. Dashner had overruled Wyrick's orders to his platoon. The exact chronology of events is unclear from the available sources, but this explanation fits the pattern of events.

249 Appleman, South to The Naktong, North to The Yalu, 74.

250 Tomedi, No Bugles, No Drums: An Oral History of the Korean War, 6; Knox, The Korean War, 24.
} 
The experience of the $34^{\text {th }}$ Infantry shows reveals similar issues albeit at a larger scale. The problems for the $34^{\text {th }}$ began with its senior officers. It's commander Loveless was an experienced soldier, in fact he was the only regimental commander in $24^{\text {th }}$ ID with WWII experience in the same position. ${ }^{251}$ However, he was still new to the $34^{\text {th }}$ and unfamiliar with his colleagues. ${ }^{252}$ Lieutenant Colonel Harold Ayres, also new, led the regiment's $1^{\text {st }}$ Battalion. Although a capable officer with WWII experience, Ayres did not join the unit until it was already at Pyongtaek and never even met Lovelace before the battle. ${ }^{253} \mathrm{He}$ was also poorly briefed before his arrival. He told his company commanders to expect a barely armed and untrained adversary instead of fierce fighters. ${ }^{254}$ The regiment's leadership lacked cohesion and familiarity with the situation and their colleagues.

Staffing turnover caused more problems with another new arrival, Brigadier General George Barth, the acting division artillery commander. Barth personally observed what happened to Task Force Smith but lacked familiarity with Dean's overall plans. He therefore told Ayres, who held Pyeongtaek with the $1^{\text {st }}$ Battalion to retreat immediately if threatened with envelopment. Barth then met with Loveless and suggested the regiment reorganize further south at Chonan. Lovelace, unsure about Barth's place in the chain of command but certain of his superior rank, ordered the $3^{\text {rd }}$ Battalion at Ansong to fall back. ${ }^{255} \mathrm{He}$ surrendered the right flank of the regiment's line without firing a shot.

Next, Loveless directed his attention to the $1^{\text {st }}$ Battalion. According to some accounts, Barth meant for Ayres to fall back to the next good defensive position if threatened. ${ }^{256}$ Whether

\footnotetext{
${ }^{251}$ Longabaugh, "Task Force Smith and the 24th Infantry Division in Korea, July 1950," 20.

${ }^{252}$ Heller and Stofft, America's First Battles 1776-1965, 272; Fehrenbach, This Kind of War: The Classic Korean War History, 74.

${ }^{253}$ Appleman, South to The Naktong, North to The Yalu, 77.

${ }^{254}$ Fehrenbach, This Kind of War: The Classic Korean War History, 73.

${ }^{255}$ Fehrenbach, 74-75.

${ }^{256}$ Gugeler, Combat Actions in Korea, 13-14.
} 
or not the case, Loveless, acting on Barth's recommendation, explicitly ordered Ayres to rendezvous at Chonan if threatened with encirclement. Accordingly, Ayres marched $1^{\text {st }}$ Battalion the full 15 miles to Chonan. To cover such a movement, Loveless instructed his regimental reserve, $\mathrm{L}$ company, to act as a rearguard and defend from successive positions if Ayres withdrew. However, when the time to withdraw came, they too joined the race south. ${ }^{257}$

As a result, despite Dean, Barth and Lovelace all appearing to want to mount some kind of defense from successive positions between Pyongtaek and Chonan; Ayres instead took his men all the way to Chonan. Poorly worded suggestions and Barth's unclear status in the chain of command conspired to cause this regrettable blunder that proper communication would have solved.

Although these incidents might be justly chalked up to the fog and friction of war, the Army's dysfunctional personnel system certainly contributed. It made continuity in training and experience impossible by saddling both the $34^{\text {th }}$ and Task Force Smith with inexperienced and unfamiliar soldiers and leaders. Consequently, both units experienced confusion and panic. In addition, the Army's leaders may simply have lacked competence. Fehrenbach, for one, claimed that many officers in Eight Army were simply incapable of leading men in combat. He further accused senior Pentagon leaders of not being in touch with reality and that their optimism "approached the dreamworld of the Imperial Japanese Government." 258

Fehrenbach's accusations are partly borne out by an analysis of American tactics during the early battles of the Korean War. U.S. commanders seemingly picked up some bad habits from WWII when American division and regimental commanders rarely operated with the frontages and reserves dictated by standard doctrine. Fighting with secure flanks against heavily

\footnotetext{
${ }^{257}$ Appleman, South to The Naktong, North to The Yalu, 79-82.

${ }^{258}$ Fehrenbach, This Kind of War: The Classic Korean War History, 102.
} 
entrenched opponents, they often committed their ample reserves to the front lines which allowed units to cover much less ground than normal. ${ }^{259}$ Korea unfolded in exactly the opposite situation with few reserves and far wider frontages. Additionally, senior commanders from WWII had little experience with conducting withdrawals, explaining why orderly retreats often turned to routs. $^{260}$

Furthermore, WWII engrained that control over road systems was imperative because of the focus on heavily mechanized weapons and transportation that required roads. ${ }^{261}$ The Army's training and tactics generally reflected travel by truck over march. ${ }^{262}$ However, few good roads existed in Korea and the enemy infantry willingly circumvented them. Trucks provided speed, but dependence on roads also limited their flexibility. In contrast, the lightly equipped North Korean leg-infantry were slower, but could transverse Korea's rough terrain. ${ }^{263}$ Some senior leaders, such as General James Gavin, recognized this problem almost immediately after WWII, but the issue persisted through to the Korean War Thus, the KPA took advantage of the American's lack of tactical mobility to flank and cut off the scattered GIs.

Evidently, numerous factors contributed to the U.S. Army's early defeats in Korea. The base level of training and motivation of the GIs was definitely poor, despite some bright spots. The first units were also too understrength and underequipped to fight according to their doctrine. Finally, numerous leadership failures occurred at all levels of command. Combined, these weaknesses: manpower; equipment; training; and leadership ensured that the U.S. Army

\footnotetext{
${ }^{259}$ Doubler, Closing With the Enemy: How GIs Fought the War in Europe, 229-35.

${ }^{260}$ Fehrenbach, This Kind of War: The Classic Korean War History, 104. Fehrenbach specifically refers to $1^{\text {st }}$ Cav commander Hobart Gay, Patton's former chief of staff, as lacking skill in retrea due to having never experienced one before.

${ }^{261}$ Doubler, Closing With the Enemy: How GIs Fought the War in Europe, 229.

${ }^{262}$ United States Army European Command Historical Division, "Final Report, Joint Field Training Exercise (Exercise Rainbow), 11-18 September 1950," 113.

${ }^{263}$ Fehrenbach, This Kind of War: The Classic Korean War History, 105.
} 
lacked an ability to engage any enemy in a ground war, least of all against the well trained KPA. $^{264}$

Each of these issues connected to the American public turning its back on the idea of traditional ground warfare. The loss of talented and experienced young leaders, either lured out by the civilian economy or culled by harsh personnel cuts, undermined leadership. Legislation and policy directives diverted money for equipment to the shiny new Air Force and reinvigorated Navy. The recruitment system also drove more educated personnel to those branches of service at the infantry's expense. Meanwhile, reformers reduced the intensity and length of basic training, ensuring a decline in capabilities. Multiple decisions across American society, all reflecting apathy for ground warfare, ensured the U.S. Army being unready for war.

And yet, despite all of these fundamental issues, despite being outnumbered by a skilled and capable adversary, the U.S. Army ultimately got the job done. True, the battles at Osan, Pyongtaek, and Taejon were textbook defeats, but early on, the strategy focused on delay, not victory while waiting for reinforcements. Unfortunately, the many deficiencies of the Army ensured too many casualties for too little time. ${ }^{265}$ However, they bought enough time. The tenacity, grit, and significant suffering of the men of the $24^{\text {th }}$ Infantry Division guaranteed that by August, the vast bulk of Eighth Army arrived on the peninsula with tens of thousands more soldiers on the way. These early battles were defeats, but not failures.

However, the U.N. forces position in August 1950 remained perilous. The North Koreans forced them into a perimeter on the southeast corner of the peninsula around Pusan and Taegu. U.N. forces held a line along the Naktong river on its western side and with high mountain

\footnotetext{
${ }^{264}$ Appleman, South to The Naktong, North to The Yalu, 180-181.

${ }^{265}$ Fehrenbach, This Kind of War: The Classic Korean War History, 101.
} 
ranges in the north. ${ }^{266}$ Despite having enough troops to form continuous lines, U.N. forces faced constant pressure from ferocious and well-coordinated KPA attacks. ${ }^{267}$ The U.S. Army needed to fix its problems quickly to hold.

For success, the easiest issue to correct was the Eighth Army's deficit of equipment. It went into battle with limited equipment, not because the nation lacked resources, but because it lacked the foresight to provide it with weapons beforehand. The U.S. industrial sector thrived in 1950 and plentiful stocks of old, but usable equipment remained from WWII. ${ }^{268}$ Equipment began arriving within weeks of the battle at Osan, especially powerful new 3.5-inch bazookas capable of countering the dreaded KPA tanks. As the Pusan Perimeter took shape, they arrived in increasing numbers alongside other previously scarce weapons including mortars, grenades, artillery, trucks, tanks, and ammunition of all types. ${ }^{269}$ Two deficiencies remained including the radios, which remained unreliable in mountainous terrain and poor weather conditions throughout the war. ${ }^{270}$ Second, the military redirected much equipment from other units around the world, leaving them leaving them underequipped.

The Army and the U.S. government also acted quickly to address the manpower issue. However, this problem required more time. The Eighth Army remained understrength, especially after taking severe casualties. In response, the Army pulled soldiers from every available source including cannibalizing support and training units for individual replacements as more units deployed from the United States. Then, in August 1950, the Army called up its organized reserves including 43,000 officers and 62,000 enlisted men, most either ROTC graduates or

\footnotetext{
266 Appleman, South to The Naktong, North to The Yalu, 252-53.

267 Appleman, 254-55; Fehrenbach, This Kind of War: The Classic Korean War History, 119-20.

${ }^{268}$ Fehrenbach, This Kind of War: The Classic Korean War History, 112.

${ }^{269}$ Longabaugh, "Task Force Smith and the 24th Infantry Division in Korea, July 1950," 11-14.

270 S.L.A. Marshall, Commentary on Infantry Operations and Weapons Usage in Korea: Winter of 1950-51, ed. George Nafziger (West Chester, OH: The Nafziger Collection Inc., n.d.), 23; Marshall, The River and the Gauntlet, 20; Fehrenbach, This Kind of War: The Classic Korean War History, 332.
} 
WWII veterans. These soldiers generally lacked good preparation for war and few wanted to serve in the Army, let alone combat. Most had an education, a job, and families. Nevertheless, tens of thousands of them soon joined the Pusan Perimeter with little to no retraining. The lucky ones deployed stateside to train the massive influx of new draftees, also called up for Korea. ${ }^{271}$

Prior to the Korean War, the draft primarily induced young men to enlist voluntarily. In the two years before the war, only eight percent of recruits were draftees. However, enlistments dropped at the outbreak of war just as the need for manpower peaked. To make matters worse, Congress, sensitive to the plight of reservists who served in WWII, limited the terms of active service for reservists. To fill its manpower needs then, the Army turned to the draft. In June 1950, President Truman ordered 50,000 men drafted between August and September. Just as in WWII, the Army relied on conscripts to sustain its fighting ability on the front lines. ${ }^{272}$

With this influx of men and material, Eighth Army finally fielded a decent force against the KPA through August and September. Although lacking enough troops to form a truly continuous battle line, Eighth Army units finally had their flanks guarded. Additionally, General Walker had enough soldiers to form a mobile reserve consisting of his best units such as the $27^{\text {th }}$ Infantry Regiment and the Provisional Marine Brigade. These "fire brigades" took advantage of the U.N. forces' interior lines of communication and mechanization to quickly plug any breaches in the perimeter. ${ }^{273}$ The KPA tanks, already the target of air attack, found themselves also vulnerable to infantry and American armor. By August fewer than 40 T-34s remained. ${ }^{274}$ The

\footnotetext{
${ }^{271}$ Linn, Elvis's Army: Cold War GIs and the Atomic Battlefield, 53-54.

${ }^{272}$ Linn, 55-56.

${ }^{273}$ Fehrenbach, This Kind of War: The Classic Korean War History, 119-20; Sandler, The Korean War: No Victors, No Vanquished, 71; Tomedi, No Bugles, No Drums: An Oral History of the Korean War, 15-28.

${ }^{274}$ Fehrenbach, This Kind of War: The Classic Korean War History, 113.
} 
North Koreans lost the quantitative and qualitative advantages that allowed them to nearly drive the U.N. off the peninsula.

General MacArthur, in overall command of the U.N. forces, used his newfound abundance of soldiers to organize an amphibious landing in the enemy rear. The ambitious plan called for the newly arrived $7^{\text {th }}$ Infantry and $1^{\text {st }}$ Marine Divisions (organized into X Corps under Lieutenant General Edward Almond) to attack the port of Inchon near Seoul. It was an incredible risk. Barrier islands, difficult tides, and a high sea wall ensured a quite defensible enemy position. Overruling the objections of the Navy and Marine commanders, MacArthur pushed ahead. ${ }^{275}$ Luckily for him, the North Koreans had failed to garrison the port itself, and they failed to deploy a shipment of Soviet naval mines. ${ }^{276}$ As a result, the landings succeeded despite sloppy execution of the complicated plan. ${ }^{277}$

The Inchon landings precipitated the complete collapse of the KPA. After months of intense combat and several fruitless assaults against the Naktong river line, the exhausted and bloodied North Koreans buckled. American artillery and airpower decimated their infantry and most of their tanks. U.N. planes relentlessly bombed North Korean supply lines, depriving the KPA soldiers of food, ammunition, and reinforcements. ${ }^{278}$ With a strong enemy force suddenly deep in their rear their morale crumbled. After initially facing strong resistance, Eighth Army's counter-offensive quickly shattered and overran fleeing KPA formations. ${ }^{279}$ It suddenly seemed U.N. forces, with the Americans at their vanguard, would win.

\footnotetext{
275 Appleman, South to The Naktong, North to The Yalu, 492-95.

276 Sandler, The Korean War: No Victors, No Vanquished, 90-93.

277 Tomedi, No Bugles, No Drums: An Oral History of the Korean War, 33.

${ }^{278}$ Fehrenbach, This Kind of War: The Classic Korean War History, 138.

279 Tomedi, No Bugles, No Drums: An Oral History of the Korean War, 63; Sandler, The Korean War: No Victors, No Vanquished, 95-98.
} 
Unfortunately, these sudden successes disguised many issues unfixed or maybe worse. Morale remained a mixed bag. On the one hand, many of the U.S. troops now had valuable combat experience. Additionally, with their backs to the ocean, and with full understanding that they now fought in a shooting war, GIs were less likely to turn tail and run when facing adversity. ${ }^{280}$ However, numerous instances existed where American troops refused to fight or follow orders. For example, Lieutenant Uzal Ent of the $27^{\text {th }}$ Infantry failed to convince artillerymen to emerge from hiding and man their howitzer during a pitched battle on the Naktong. ${ }^{281}$ Making matters worse, most reservists arriving as replacements resented being pulled back into service. ${ }^{282}$ Importantly, the American troops still did not fully understand the mission.

At the same time, training, if anything, deteriorated in the initial months of the war. To accommodate the massive influx of draftees, the Army reduced its training program to six weeks. ${ }^{283}$ At the same time, many training units lost their most capable personnel who headed to Korea. Reservists who varied considerably in experience and competence replaced them. Although some reserve instructors brought valuable experience from WWII to the training camps, others remained disgruntled and disinterested in their new duty. In one training division, many of the cadre were illiterate and they went AWOL proportionally more often than recruits. ${ }^{284}$ Given the fact that the basic training program was already poor, these changes ensured high casualty rates for new replacements.

\footnotetext{
${ }^{280}$ Fehrenbach, This Kind of War: The Classic Korean War History, 157.

${ }^{281}$ Tomedi, No Bugles, No Drums: An Oral History of the Korean War, 21.

${ }^{282}$ Linn, Elvis's Army: Cold War GIs and the Atomic Battlefield, 53-54.

${ }^{283}$ Pash, In the Shadow of the Greatest Generation, 56; Bornstein et al., "Measures of Combat Performance in Korea. Volume 3: Comparison of Measures for Men Trained Under Peacetime and Mobilization Basic Training Programs." ${ }^{284}$ Linn, Elvis's Army: Cold War GIs and the Atomic Battlefield, 65.
} 
Leadership failures also continued to plague the Army. Young lieutenants like Ernst, a West Point washout who made it back into the Army through OCS, made poor decisions under fire like sending the unit medic to the rear with a minimally injured man preceding a major battle. ${ }^{285}$ Other officers, like those in charge of A company $34^{\text {th }}$ infantry, made tactical mistakes while leading their men in battle. During a counter attack along the Naktong, the two leading platoon leaders recklessly got themselves shot in the opening minutes of the engagement. Meanwhile, the company commander, displaying weak leadership from the rear, failed to effectively direct his platoons or make use of supporting artillery and mortars. As a result, the counter offensive failed despite individual heroic acts. ${ }^{286}$

FECOM reported leadership failures like these were widespread at the regiment level and below across Eighth Army. ${ }^{287}$ That the Army’s field commanders performed poorly in combat should not have been surprising. West Point's reputation for producing capable officers was in serious declines well before the Korean War began. ${ }^{288}$ Officers from ROTC and OTS also gained a reputation for lacking maturity and confidence. ${ }^{289}$ On top of everything, the Army's personnel system insisted on rotating new officers through active combat units for on-the-job training rather than dedicated advanced instruction courses. ${ }^{290}$ The result was that frontline units had many officers of questionable capability.

These continuing problems of training, morale and leadership, in part, led to the disastrous end of the U.N. counter-offensive that turned into an invasion. On September $27^{\text {th }}$, with the KPA effectively destroyed, political and military leaders in Washington instructed

\footnotetext{
285 Tomedi, No Bugles, No Drums: An Oral History of the Korean War, 18-19.

${ }^{286}$ Gugeler, Combat Actions in Korea, 26-29.

287 Sandler, The Korean War: No Victors, No Vanquished, 69.

${ }^{288}$ Linn, Elvis's Army: Cold War GIs and the Atomic Battlefield, 25-27.

${ }^{289}$ Jaques, “United States Army Infantry Training Program Effectiveness During the Korean War," $83-84$.

290 Jaques, 36-37.
} 
MacArthur (who had encouraged the decision) to advance to the Yalu river and reunify Korea under Syngman Rhee. ${ }^{291}$ This order came with the caveat that MacArthur should not proceed if Chinese or Soviet intervention appeared likely. Of course, they only reached this decision because they almost all, erroneously, believed that the USSR and PRC had neither the will nor means to intervene. ${ }^{292}$

A full explanation of the assumptions, reasoning, and intelligence blunders that led to that failure would fill a book, but there was plenty of blame to share ${ }^{293}$ However, T.R. Fehrenbach, normally a staunch champion of the primacy of military professionals in military affairs, castigated U.S. leaders for making MacArthur responsible for evaluating whether the Chinese would deploy their army. This was a political question rather than a military one and "such decision is not, and will never be, within the competence of military intelligence."294 Unfortunately, U.S. civil authorities focused more on protecting soldiers from being corrupted by a beer ration than the Chinese response. ${ }^{295}$

In any event, American soldiers soon raced north of the $38^{\text {th }}$ parallel to finish off the last remnants of the DPRK. Doing so, they became increasingly spread out and disorganized. Korea's central mountain ranges inhibited communications between U.N. forces in the east (Eighth Army) and the west (X Corps). Meanwhile, the supply lines stretched 120 miles across

\footnotetext{
${ }^{291}$ Fehrenbach, This Kind of War: The Classic Korean War History, 181.

${ }^{292}$ Cumings, The Korean War: A History, 22-23.

${ }^{293}$ Cumings and Fehrenbach both discuss this issue at length. Cummings focuses on the influences of MacArthur's personal biases and military intelligence failures. Fehrenbach looks more broadly to the weakness of U.S spy agencies and diplomatic intelligence in Asia as well as misinterpretation of the situation by multiple high-level figures. For his part, Matthew Ridgeway wrote in his memoirs that he believed MacArthur willfully ignored obvious signs of a possible intervention so Truman and the Joint Chiefs would allow him to continue the offensive.

${ }^{294}$ Fehrenbach, This Kind of War: The Classic Korean War History, 182.

${ }^{295}$ Fehrenbach, 158.
} 
rough terrain and bombed out infrastructure. Thus, the overconfident UNC forces were exceedingly vulnerable to attack as they approached the Yalu in mid-October. ${ }^{296}$

Unbeknownst to them, the Chinese had prepared to take advantage of their weakness. Operating under the title of the People's Volunteer Army (PVA), the Chinese $38^{\text {th }}, 39^{\text {th }}, 40^{\text {th }}$, and $42^{\text {nd }}$ armies, comprising over 120,000 men, arrived in Korea by October $15^{\text {th }}$. Marching at night and carefully concealing themselves by day, aerial reconnaissance never detected their presence. The $50^{\text {th }}$ and $66^{\text {th }}$ armies and the reinforced IX Army Group, another 180,000 soldiers, were on the way. ${ }^{297}$ Contrary to all the expectations of the U.S. military and government, the Chinese planned a forceful intervention.

The first Chinese attacks had a relatively limited impact compared to what followed. On 25 October, they struck the mountainous seam of the UNC formation along Eight Army's right and X Corps' left flanks inflicting heavy damage. However, after several days of savage fighting, the PVA withdrew and broke contact, intending to draw in the UNC for the next attack. ${ }^{298}$ General Walker, realizing what he now faced, recoiled and consolidated Eighth Army south of the Chongchon river. The $1^{\text {st }}$ Marines, fighting under General Oliver Smith as part of X Corps, likewise consolidated their position. However, after several weeks passed, and no further attacks came, MacArthur grew impatient with his subordinates' caution and ordered them to resume the advance. ${ }^{299}$ On November $25^{\text {th }}$, the soldiers of the UNC set out on the ill-fated Home-byChristmas Offensive, walking straight into the teeth of the PVA.

\footnotetext{
${ }^{296}$ Ridgway, The Korean War, 47-49.

${ }^{297}$ Billy Mossman, Ebb and Flow: November 1950-July 1951 (Washington, D.C.: Center of Military History, U.S. Army, 1990), 53-54; Fehrenbach, This Kind of War: The Classic Korean War History, 193.

${ }^{298}$ Mossman, Ebb and Flow: November 1950-July 1951, 59-60.

${ }^{299}$ Ridgway, The Korean War, 53-65.
} 
The PVA's Second Phase Offensive struck the UNC like a hammer blow. Walker expected to meet resistance on Eight Army's right flank but was still faced demolition by hidden Chinese formations. Meanwhile, the enemy stopped and threatened to encircle X Corps' $1^{\text {st }}$ Marines and $7^{\text {th }}$ Infantry. ${ }^{300}$ In these battles the PVA relied on similar tactics to those of the KPA earlier in the war. They slipped in and around the fragmented UNC lines, cutting off and attacking units left isolated by either darkness or mountainous terrain. ${ }^{301}$

There were three principal differences, however, between this offensive and the one that started the war. First, the PVA, by evading detection through camouflage and strict march discipline, achieved near complete tactical surprise in the initial hours of their attack. ${ }^{302}$ Second, they lacked an absolute advantage in manpower, so they bypassed some units and crushed others. ${ }^{303}$ Finally, they won without armored support or a sizable stockpile of motor vehicles. ${ }^{304}$ It was a form of simple, subtle, and sublime infantry fighting that proved effective in North Korea's craggy terrain.

Through these tactics, the Chinese handed the U.S. military its worst defeat ever in terms of miles lost. Ultimately Eight Army retreated 120 miles back to the $38^{\text {th }}$ parallel by December $23^{\text {rd }}$. Throughout the battles and the march south, many examples of the continuing weaknesses of the U.S. Army manifested themselves. Captain Sherman Pratt of the $23^{\text {rd }}$ Infantry, $2^{\text {nd }}$ ID recounted how he witnessed shocked and panicked GIs who fled in confusion when they faced Chinese envelopment. ${ }^{305}$ Lieutenant Andy Bar, a forward observer with a mortar company, watched in disgust as men snuck away from the lines to safety. ${ }^{306}$ In another case, Battery A, $61^{\text {st }}$

\footnotetext{
${ }^{300}$ Ridgway, 69-71.

${ }^{301}$ Fehrenbach, This Kind of War: The Classic Korean War History, 200-201.

302 Mossman, Ebb and Flow: November 1950-July 1951, 55.

${ }^{303}$ Fehrenbach, This Kind of War: The Classic Korean War History, 204.

${ }^{304}$ Ridgway, The Korean War, 51; Fehrenbach, This Kind of War: The Classic Korean War History, 201.

305 Tomedi, No Bugles, No Drums: An Oral History of the Korean War, 64-65.

306 Tomedi, 74.
} 
Field Artillery abandoned its guns after losing its officers, either killed or wounded. ${ }^{307}$ Most famously, large elements of the $2^{\text {nd }}$ ID came almost completely unglued after the Chinese trapped the retreating column in a ravine. Much slaughter ensued. ${ }^{308}$

However, the Great Bug-Out, as some called it, could have been worse. ${ }^{309}$ True, deficiencies in the training and discipline of the American GIs remained unresolved and many field commanders still made mistakes. ${ }^{310}$ However, the U.S. Army was in better shape than the start of the war. The Americans had more equipment, men, and experience to meet this offensive. Some units, like B Company, $9^{\text {th }}$ Infantry Regiment, fought bravely and effectively against overwhelming odds. ${ }^{311}$ Good officers, like soft-spoken $2^{\text {nd }}$ Lieutenant Dale G. Hollingsworth of G Company $38^{\text {th }}$ Infantry, stayed cool under fire, took charge, inspired their men to action, and saved who they could..$^{312}$

At the very top, now battle-wise generals like Walker and Smith responded to a critical situation with prudence and skill. Eighth Army's long retreat may have been embarrassing, but Walker planned it carefully. As a result, Eight Army escaped largely intact and avoided a potential envelopment on its vulnerable right. ${ }^{313}$ In the East, X Corps, with Smith's Marines at its core, performed outstandingly in its withdrawal and evacuation from the port of Hungnam. It inflicted severe casualties on the PVA IX Army Group (leaving it combat non-effective), rescued approximately 100,000 civilian refugees, recovered all useful equipment in its area, and blew up

\footnotetext{
${ }^{307}$ Sandler, The Korean War: No Victors, No Vanquished, 122.

${ }^{308}$ Fehrenbach, This Kind of War: The Classic Korean War History, 225-32.

309 Tomedi, No Bugles, No Drums: An Oral History of the Korean War, 65.

${ }^{310}$ Fehrenbach, This Kind of War: The Classic Korean War History, 224; Marshall, The River and the Gauntlet, 11617.

${ }^{311}$ Marshall, The River and the Gauntlet, 18-40.

312 Marshall, 125-33.

${ }^{313}$ Mossman, Ebb and Flow: November 1950-July 1951, 150-65; Fehrenbach, This Kind of War: The Classic Korean War History, 252-55.
} 
everything else. In exchange it suffered about 8,700 total casualties. ${ }^{314}$ It was certainly no victory for the UNC, but hardly the disaster it could have been.

Still, hundred-mile retreats never lend themselves to positive press coverage. A shocked American people tried to comprehend how not once, but twice in less than sixth months their vaunted military suffered setbacks at the hands of third-world armies. ${ }^{315}$ The shock of these winter defeats finally pushed the Army to deeply examine its training programs and implement significant reform.

To start, the Army expanded initial training to sixteen weeks split between basic and advanced training and resurrected old WWII battle indoctrination courses. ${ }^{316}$ New training publications included improved evaluation techniques and training schedules shifted dramatically away from drill and inspections to important combat skills like night fighting and physical conditioning. ${ }^{317}$ In Korea too, stabilizing battle lines allowed deployed units to conduct in-theater training and get their replacements up to speed. ${ }^{318}$ As Fehrenbach reminisced, "slowly, commanders then began to restore the old hard slap and dash." 319

Evaluating the actual impact of these reforms however, is somewhat difficult. The decision by Truman and the U.N to abandon the goal of reunifying Korea, combined with the limitations of Chinese logistics, ended large-scale offensives on the peninsula. Naturally, this meant fewer troops in combat similar to the earlier stages of the war. Instead of a war of

\footnotetext{
314 Tomedi, No Bugles, No Drums: An Oral History of the Korean War, 100; Sandler, The Korean War: No Victors, No Vanquished, 123-27; Mossman, Ebb and Flow: November 1950-July 1951, 147-48. Sandler estimated Chinese total casualties of approximately 70,000, significantly higher than most other estimates.

${ }^{315}$ Fehrenbach, This Kind of War: The Classic Korean War History, 251-251.

${ }^{316}$ Jaques, "United States Army Infantry Training Program Effectiveness During the Korean War," 55-76.

317 "The Basic Training Guide" (Military Services Publishing Company, 1951), 314-16 323-24, U113 .B38 1951, U.S. Army Heritage and Education Center.

318 Jaques, "United States Army Infantry Training Program Effectiveness During the Korean War," 82.

${ }^{319}$ Fehrenbach, This Kind of War: The Classic Korean War History, 224.
} 
maneuver, it became a war of outposts, trenches, artillery, and attrition. Nonetheless, one can glean some conclusions from the available sources.

To begin with, more and better training in basic and AIT seems to have improved soldiers' technical skills to the point where division commanders found replacement troops acceptably proficient by $1952 .{ }^{320}$ However, morale and discipline remained a mixed bag. By Spring of 1951, men still lacked information about why they fought. But they increasingly recognized they lived in a war of attrition with little chance of a quick victory. ${ }^{321}$ Later, in late 1952, many new trainees wrongly expected the war to end before they deployed, something the armistice talks encouraged. ${ }^{322}$ It was hardly an optimal attitude for new infantrymen.

Additionally, contemporary studies indicated that not all training reforms enhanced actual combat performance. One study from mid-1952 found that, all else being equal, the length of basic training had no significant impact on combat performance. Instead, overall time in service better determined combat performance. ${ }^{323}$ Another 1951 study noted that "the permanent effect on fear of 'battle inoculation' (the procedure in which live ammunition is fired over troops during training exercises) is suspect. Although it is likely that battle inoculation would have good short-term effects on fear, these would be expected to die away in a matter of hours." 324 Thus, many changes may have had little practical value.

However, other evidence to suggested that training had significantly improved. An excellent example arose from the experience of Jerry Spangler. In late 1950, during the PVA's offensives, Spangler was a pilot in the Naval Air Corps Reserve. An avid diver as well, Spangler

\footnotetext{
320 Jaques, “United States Army Infantry Training Program Effectiveness During the Korean War," 81.

${ }^{321}$ Tomedi, No Bugles, No Drums: An Oral History of the Korean War, 125-29.

322 Stickle, So They Will Know: A Korean War Memoir, 34.

${ }^{323}$ Bornstein et al., "Measures of Combat Performance in Korea. Volume 3: Comparison of Measures for Men Trained Under Peacetime and Mobilization Basic Training Programs," 7-9.

${ }^{324}$ Kenneth Yarnold, "Fear in Battle" (Research and Development Board. Working Group on Human Behavior under Conditions of Military Service, 1951), 3, U393.5 .U55 Appx.177, U.S. Army Heritage and Education Center.
} 
was exactly the type of intelligent, fit young men the Army desperately needed more of, but often lost to colleges or the other services. However, when Spangler injured his foot in an accident, he landed on his squadron's inactive roster which made him eligible for the draft. His local board wasted no time. Over his squadron commander's protest, Spangler ended up in the Army as an infantryman before his injury healed. ${ }^{325}$

Needless to say, Spangler lacked enthusiasm for his new job. Regarding his first days of basic he proclaimed "I hated it; I didn't want to be in the damned Army I wanted to fly!" Despite his disappointment, Spangler took well to infantry training. At Fort Ord California, he first received eight weeks of basic training which he rated highly for getting him physically fit and instilling discipline. He went through this training as part of a platoon assigned a single DI, a departure from the Army's previous committee model for training. In advanced training, he recalled: "It was a lot more severe as far as spending more hours at night and in the wilderness living on our own out in the woods and up in the mountains." Spangler learned combat skills, familiarized himself with weapons, especially grenades and mortars, and enhanced his physical conditioning. 20-mile marches, sometimes at night, were a normal occurrence. Ultimately, Spangler felt prepared upon leaving Fort Ord, concluding "I think we got a pretty good training. $" 326$

Arriving in Korea in September 1951, however, Spangler had more work ahead of him. "The training never stopped, you learned something new every day," he remembered. Spangler joined a machine gun squad as part of the $35^{\text {th }}$ Infantry, $25^{\text {th }}$ ID. He quickly advanced from a lowly ammo bearer to a gunner for one of the .30 caliber Brownings within a month. Five months later, he was the squad leader. Seeing some of the fiercest combat of the war at the battle

\footnotetext{
325 Jerry Spangler, Jerry Spangler's Korean War Experience, Oral History, September 26, 2020.

326 Spangler.
} 
of Triangle Hill and other engagements in the Iron Triangle, Spangler served with distinction. Twice wounded by artillery, he eventually rotated home in April 1953. At least in this instance then, the Army's revamped training well prepared a young soldier for the rigors of war. ${ }^{327}$

Unfortunately, these reforms in training came too late for many young soldiers who became casualties earlier in the war. Among these men, the POWs became the biggest symbols of the Army's failure to properly train its soldiers. Ultimately, the communists captured an estimated 6,656 U.S. soldiers, with the vast bulk taken captive in the first year of the war. ${ }^{328}$ Only 4,435 Americans, 3,973 of them Army personnel, returned to the United States alive. ${ }^{329}$ A particular perception of American POWs in Korea developed in the country's public consciousness. For example, a number of American films about the war, such as The Rack and The Manchurian Candidate, focus on the suffering and defection of POWs. Engineered by writers like Eugene Kinkeade, they argued that American POWs of the Korean War behaved shockingly bad under relatively lenient conditions. To substantiate his claims, Kinkead used dubious statistics and suspicious sources showing unprecedented death rates and rampant collaboration among American POWs. ${ }^{330}$ For these failings, Kinkead blamed faulty military training and an increasingly decadent and soft culture. ${ }^{331}$

A number of scholars have since pinpointed many flaws in Kinkead's work. Despite his claims to the contrary, American soldiers often endured incredibly harsh treatment, especially from the North Koreans. Early in the war, POWs quickly learned that any disobedience could

\footnotetext{
${ }^{327}$ Spangler. Spangler himself refers to the battle of triangle hill exclusively as the battle of hill 717.

${ }^{328}$ William Latham, Cold Days in Hell: American POWs in Korea (College Station TX: Texas A\&M University Press, 2012) Appx.

${ }^{329}$ Latham, 230.

${ }^{330}$ Kinkead, In Every War But One, 17.

${ }^{331}$ Kinkead, 88-107.
} 
result in a summary execution. ${ }^{332}$ One of the most notorious examples of this behavior became known as the Tiger Death March. On a hellacious forced march in freezing temperatures, American POWs suffered from starvation, exposure, dysentery and summary execution at the hands of North Korean police should they fall too far behind. ${ }^{333}$

Additionally, medical care was often non-existent within the camps and the rations extremely poor in both quality and quantity. Sanitation ranged from decent to abysmal depending on the camp. ${ }^{334}$ These desperate conditions, combined with the Chinese' novel use of prisoners for propaganda purposes, largely accounted for many failings by American POWs. ${ }^{335}$ The account of David Green, a British POW of the Gloucestershire Regiment taken prisoner in April 1951, highlights just how harsh conditions were.

[The American sector's] occupants, looking grey and gaunt, shuffled around aimlessly, having clearly abandoned all hope. Their sick lay at the roadside by day, being gathered up by their mates at sunset, and dragged into their houses.... Every day we would see their burial squad, shovels in hand, making two or even three trips up the little hill to the cemetery.... It was also plain that the Yanks were not embraced by the 'lenient policy' that we had been promised and had a much tougher time than we did. ${ }^{336}$

In one important respect however, Kinkead was right. The Army had failed to train its men regarding their rights and responsibilities as POWs. One report on the subject, released in mid-1951, criticized the Army for making no significant effort to do so, especially when the results of this policy already existed from the experience of POWs in the Philippines during WWII. ${ }^{337}$ As a result, thousands of POWs had no comprehension of expectations or rights in

\footnotetext{
${ }^{332}$ Latham, Cold Days in Hell: American POWs in Korea, 231; Tomedi, No Bugles, No Drums: An Oral History of the Korean War, 12-13.

${ }^{333}$ Latham, Cold Days in Hell: American POWs in Korea, 48-57.

${ }^{334}$ David Green, Captured at the Imjin River: The Korean War Memoirs of a Gloster (South Yorkshire, UK: Pen and Sword Military, 2003), 115-17; Latham, Cold Days in Hell: American POWs in Korea, 129-34.

${ }^{335}$ Latham, Cold Days in Hell: American POWs in Korea, 3.

${ }^{336}$ Green, Captured at the Imjin River: The Korean War Memoirs of a Gloster, 115-16.

${ }^{337}$ Lewis, "Prisoner of War Survival," 4.
} 
ensuring their own survival. For instance, they had no understanding that adhering to military discipline and keeping active and fit while imprisoned were essential to their survival. ${ }^{338}$ It was a tragic oversight that the military did not correct until well after the end of the Korean War. ${ }^{339}$

Prisoners of war clearly showed the problems with training and how they translated to negative effects on the battlefield in Korea. After all, few know how to perform without guidelines, especially in relation to something so complex and extraordinary. In other aspects of the war however, the connection between training and combat performance is far murkier. There is good anecdotal evidence to suggest that better trained soldiers and units performed better in combat. However, other evidence indicates that significant changes to training created only marginal improvements in combat effectiveness. From this particular historical example, it appears there may be limits to the importance of training quality in combat.

Additionally, the Army's early failures in Korea were more than just training. The poor state of the Army's equipment and manpower pool at the outset of conflict significantly impacted the effectiveness of the $24^{\text {th }}$ ID in the earliest engagements. Leadership at multiple levels failed throughout 1950 and morale was a continuous problem. These widespread and diverse issues are evidence that the cause of the U.S. Army's failures in Korea go beyond any single aspect of its organization.

Rather, they may point to a systematic weakness born of American cultural attitudes regarding war. Specifically, Americans, both historically and after WWII in particular, did not consider preparing for ground warfare a significant priority unless absolutely necessary to defend a core interest. As a result, Americans fashioned a peacetime Army designed to achieve civilian economic and moral priorities rather than provide an effective battle-ready force. Given the skill

\footnotetext{
${ }^{338}$ Green, Captured at the Imjin River: The Korean War Memoirs of a Gloster, 116-17.

${ }^{339}$ Latham, Cold Days in Hell: American POWs in Korea, 241-43.
} 
and bravery of the KPA and PVA, a stalemate was probably the best outcome such an Army could hope to achieve without resorting to total mobilization or global nuclear war. 


\section{Conclusion: An Un-American Way of War?}

Writing thirteen years after the Korean War ended, T.R. Fehrenbach castigated the United States for failing to prepare its soldiers to fight in Korea. "They had been raised to believe the world was without tigers, then sent to face those tigers with a stick. On their society must fall the blame" he fumed. ${ }^{340}$ More recently, scholars have challenged Fehrenbach, claiming he overstated the issue. Thomas Hanson, seeking to restore the Eighth Army's reputation, wrote that Fehrenbach's “sweeping generalizations ... eliminated the distinction between operational and strategic blunders committed by those serving at theater level and higher and tactical failures by soldiers and officers in the field." ${ }^{341}$ Brian Linn agreed, insinuating that Fehrenbach's assessment constituted little more than militaristic mythmaking meant to exculpate the generals at the expense of the common soldier. ${ }^{342}$ These scholars viewed Fehrenbach's accusations as an outdated orthodoxy lacking objectivity.

However, the U.S. government failed to prepare its soldiers for Korea. Congress and accommodating military leaders designed personnel and recruitment systems to prioritize civilian concerns and left the Army, and the infantry especially, undermanned. They reduced basic training to save money and shifted its focus away from combat to make Army life more attractive to the public and volunteers. Likewise, they relaxed discipline to improve the service's image and attract volunteers. They assigned officers based on standard career progression models rather than ability or field of expertise. Meanwhile, frontline units lacked the resources

\footnotetext{
${ }^{340}$ Fehrenbach, This Kind of War: The Classic Korean War History, 84.

${ }^{341}$ Hanson, Combat Ready? The Eight U.S Army on the Eve of the Korean War, 7-8.

${ }^{342}$ Linn, Elvis's Army: Cold War GIs and the Atomic Battlefield, 71.
} 
and expertise to conduct their own training effectively. As a result, once in combat, many soldiers lacked the skills and discipline to fulfill their duty.

However, although U.S. Army training and recruitment practices were undoubtedly deficient, Linn correctly highlights that they do not entirely explain the Army's defeats. ${ }^{343}$ Early on, during the $24^{\text {th }}$ Infantry Division's delaying campaign, the lack of equipment and dearth of available forces hampered U.S. troops in mounting an effective defense, even if they fought well. Perhaps even more damaging, leadership mistakes at all levels plagued the Army's efforts throughout the war. For example, MacArthur and other high-level leaders' mistakes largely caused the debacle with the Chinese offensives in November and December of 1950. All told, a constellation of factors caused the U.S. military's defeats in Korea.

Those factors had a single source in common. American culture was ill-disposed towards ground warfare. The incompatibility went beyond the tired refrain of Americans being too individualistic to accept military discipline, although that played a role. Rather, Americans, both collectively and individually, rarely saw preparing for ground warfare as a worthwhile endeavor. As a career path, it lacked the prestige and stability offered by the civilian economy. As an instrument of policy, it was too slow, costly, and morally and economically inefficient for a utilitarian-minded public and its leadership. When viable alternatives like air and sea power existed, most Americans wanted to avoid ground warfare.

This mindset undergirded every decision leading into America's lack of preparation for the Korean War. The Army went without men and equipment because the public wanted resources spent elsewhere. Instead of joining the Army, men wanted jobs and families. The money for equipment went to new machines that would win wars more cheaply and quickly. To

\footnotetext{
${ }^{343}$ Linn, 70-72.
} 
survive, the Army adapted to meet the public's needs. It shifted its recruitment, training, and discipline systems to become closer to a national vocational program than a combat force. Many Americans accepted the cost a large standing army, even one significantly shrunken in peacetime, only if it served purposes beyond ground warfare. ${ }^{344}$

Even once war erupted, the American people proved unenthusiastic towards the war on the ground. As a result, once disaster at Pusan no longer seemed likely, the public mood and political rhetoric turned towards swift and decisive victory and bringing the men home; thus, encouraging MacArthur and his staff to make reckless errors which widened the war. ${ }^{345}$ Even MacArthur himself, a career soldier, relied heavily on air and sea power in his strategic thinking. $\mathrm{He}$, and many other Americans, believed amphibious invasions and strategic bombing directly against China could secure a quick, cheap, and clean victory. ${ }^{346}$ Ground warfare, however, never held such promise. It was slow, bloody, and ugly and therefore diametrically opposed to how Americans wanted to fight. The infantry fighting in Korea was therefore, in many ways, an unAmerican way of war.

This cultural aversion to ground warfare was not some kind of new softness that emerged just for the Korean War. Rather, it is a persistent feature of American society. It, along with opposition to standing armies on political grounds, explain why Americans never spent resources on a large standing Army prior to the Cold War. This necessarily prevented the kind of long-term training that makes professional militaries so effective. As a result, when America raised armies, they typically punched under their weight. Most of America's military victories before Korea

\footnotetext{
${ }^{344}$ Mundy, American Militarism and Anti-Militarism in Popular Media 1945-1970, 30-37.

${ }^{345}$ Fehrenbach, This Kind of War: The Classic Korean War History, 180-86.

${ }^{346}$ Mundy, American Militarism and Anti-Militarism in Popular Media 1945-1970, 54-59.
} 
came against opponents that were inherently weaker or already drained, the sole possible exception being the Mexican-American War.

After the Korean War, American cultural attitudes towards ground war also limited the U.S. ability to achieve its battlefield goals. In Vietnam, soldiers went into battle with more equipment and newer technologies, but that could not overcome the same draft induced deficiencies in recruitment or failure to understand why soldiers fought that fouled the Korean War pipeline. Additionally, strategic mistakes regarding Vietnam echoed those of Korea. Once again, U.S. political leaders, sought a quick victory on the cheap, with a small ground force backed by airpower. ${ }^{347}$ Shortly afterward, the war turned into a long bloody slog as military and civilian leaders shoveled in more recruits to correct their miscalculation.

Even after the advent of the All-Volunteer Force, the American Army has continued to underwhelm. Its much-lauded victory in the 1991 Gulf War came only with the assistance of a massive coalition against an Iraqi Army fresh off a brutal eight-year war with Iran and after a 6month buildup and month-long aerial bombardment. In that war, the Army had the additional advantage of a reasonably limited objective.

Outside of this ideal scenario, the Army achieved only inconclusive results in the Global War on Terror. Once again, top level decision makers sent too few men to face a challenging foe, necessitating a later buildup that only prolonged the conflict. Additionally, problems with training that the AFV supposedly solved soon resurfaced in the deplorable spectacle of Abu Gharib and the combat performance of some National Guard units, fighting in an intractable war with many complexities. ${ }^{348}$

\footnotetext{
347 James Corum and Wray Johnson, Airpower in Small Wars: Fighting Insurgents and Terrorists (Lawrence KA: University Press of Kansas, 2003), 267-70.

${ }^{348}$ Scott Gold, “Guardsmen Say They're Facing Iraq Ill-Trained," Los Angeles Times, November 25, 2004, sec. World \& Nation, https://www.latimes.com/world/middleeast/la-na-guard25nov25-story.html.
} 
That these same deficiencies occur again and again in American wars indicates a pattern, beyond the scope of particular administrations or commanders, reflecting America's consistent lack of cultural affinity for ground warfare, or at least against conducting ground warfare effectively. The evidence of the Korean War demonstrates the consequences when U.S military policy disregards this innate limitation in creating, sustaining, and utilizing large, ground-based combat forces.

To be clear, that American society disregards ground warfare is not a defect. Societies rarely exist solely for waging war; they exist to improve the lives of their members. Therefore, the way Americans think about war is not necessarily a problem needing a solution. It is a problem, however, that the American people and their leaders so consistently and so grossly overestimate the Army's abilities and continually assign it missions beyond its capability. It is not wrong to prefer butter to guns, but Americans should not expect to fight as often as they do.

Future policy-makers should recognize this lesson from the Korean War. There are limits to the U.S. Army's abilities which do not simply disappear through changes in policy. Armies are products of their society, and American society does not value ground warfare. Therefore, policy makers must try to avoid fighting such wars at all costs. War in general should always be a last resort, but ground wars has proven especially treacherous for Americans. If they must put boots on the ground, it should be done under as overwhelmingly favorable conditions as possible. If the public and its representatives balk at the cost of such a scenario, then the war is probably not worth waging.

In fairness, however, there are limits to the applicability of this conclusion. This, after all, is only a single, relatively limited study of a single conflict. If anything, this analysis has shown that success and failure in war occur because of many factors which defy unifying theories. A truly 
comprehensive study of American cultural attitudes towards war and their effects on the battlefield would take up life's work. Additionally, more research remains regarding training in the Korean War in particular. The scholarly and military community needs a detailed, singularly focused analysis of the methods of infantry training used between 1946 and 1950 as well as comparative studies between training in the U.S. Army and other, similar forces such as the Marine Corps and British Army over the same time period and beyond. Such research will help shed light on an understudied and controversial question. 


\section{References}

\section{Unpublished Primary and Archival Sources:}

8th Army Headquarters. "Summary of Personnel Problems from Activation to Occupation: Yokohama, Japan, 1 February 1947," 1947. 03-8 1947 / 3. U.S. Army Heritage and Education Center.

"Basic Military Training: A Comprehensive Manual of Military Training." Military Services Publishing Company, 1943. U408.3 .B37 1943. U.S. Army Heritage and Education Center.

Berkshire, J.R., and T.H. Harrell. "General Principles of Effective Training and Training Organization." Research and Development Board. Working Group on Human Behavior under Conditions of Military Service, 1951. U393.5 .U55 Appx.200. U.S. Army Heritage and Education Center.

Bornstein, Harry, Cecil Johnson, Barry Jensen, David Yaukey, and Joel Campbell. "Measures of Combat Performance in Korea. Volume 3: Comparison of Measures for Men Trained Under Peacetime and Mobilization Basic Training Programs.” Adjutant-General's Office. Personnel Research Section, 1952. DS921.5.P4 M42 1952. U.S. Army Heritage and Education Center.

Joseph DeHaan Korean War correspondence (2015.084.w.r), Center for American War Letters Archives, Chapman University, CA.

Drucker, Arthur, Kenneth Bradt, and David Yaukey. "Strengths and Deficiencies of Precombat Training as Reported by Infantrymen in Korea." Adjutant-General's Office. Personnel Research Section, 1952. DS921.5.P4 D782 1952. U.S. Army Heritage and Education Center.

"Individual Training in Collecting and Reporting Military Information : A Guide to Assist the Commander of a Small Unit in Promoting Realistic Training." Office, Chief of Army Field Forces, 1951. UB250 .I53 1951. U.S. Army Heritage and Education Center.

Kluckhohn, Clyde. "American Culture and Military Life." Research and Development Board. Working Group on Human Behavior under Conditions of Military Service, 1951. U393.5 .U55 Appx.106. U.S. Army Heritage and Education Center.

Lewis, R.B. "Prisoner of War Survival." Research and Development Board. Working Group on Human Behavior under Conditions of Military Service, 1951. U393.5 .U55 Appx.112. U.S. Army Heritage and Education Center.

“New Soldiers' Attitudes -- After Six Weeks of Training 1, Trends in Adjustment and Orientation." Armed Forces Information and Education Division. Attitude Research Branch, 1951. U22.3 .N49 1951. U.S. Army Heritage and Education Center.

"New Soldiers' Attitudes -- after Six Weeks of Training. 2. Reactions to Training." Armed

Forces Information and Education Division. Attitude Research Branch, n.d. U22.3 .N493 1951. U.S. Army Heritage and Education Center.

Personnel Conference (1949). "Personnel Conference, 23-24-25 May 1949: Summary of Presentations.” Personnel and Administration Division, General Staff, U.S. Army, 1949. UB23 .P48 1949. U.S. Army Heritage and Education Center. 
Spangler, Jerry. Jerry Spangler's Korean War Experience. Oral History, September 26, 2020. “The Basic Training Guide.” Military Services Publishing Company, 1948. U408.3 .B372 1948. U.S. Army Heritage and Education Center.

“The Basic Training Guide.” Military Services Publishing Company, 1951. U113 .B38 1951. U.S. Army Heritage and Education Center.

United States Army European Command Historical Division. "Final Report, Joint Field Training Exercise (Exercise Rainbow), 11-18 September 1950.” Joint Headquarters FTX-50, 1950. U253.2.R34 F56 1950. U.S. Army Heritage and Education Center.

Uphoff, Howard. "Indoctrination and Basic Training." Research and Development Board. Working Group on Human Behavior under Conditions of Military Service, 1951. U393.5 .U55 Appx.171. U.S. Army Heritage and Education Center.

Yarnold, Kenneth. "Fear in Battle." Research and Development Board. Working Group on Human Behavior under Conditions of Military Service, 1951. U393.5 .U55 Appx.177. U.S. Army Heritage and Education Center.

\section{Published Primary Sources:}

"2-Way Traffic: Retreat and Advance: WARN YANKS' POSITION MAY BE UNTENABLE." Chicago Daily Tribune (1923-1963); Chicago, Ill. December 3, 1950, sec. Part 1.

Baldwin, Hanson. "Not Victory, Not Defeat: But Another War, Marked by Shining Deeds as Well as Misery, Passes Into History." New York Times. July 28, 1953.

Black, Norman, ed. Combat Veterans' Stories of the Korean War. Vol. 1. 2 vols. CreateSpace Independent Publishing, 2016.

Gold, Scott. "Guardsmen Say They're Facing Iraq Ill-Trained." Los Angeles Times, November 25, 2004, sec. World \& Nation. https://www.latimes.com/world/middleeast/la-naguard25nov25-story.html.

Green, David. Captured at the Imjin River: The Korean War Memoirs of a Gloster. South Yorkshire, UK: Pen and Sword Military, 2003.

Johnston, Richard. 'Korea Shakes G.I.'s Faith In U.S. Arms Superiority: G.I.'S FAITH SHAKEN IN U.S. SUPERIORITY Spearheaded by 60-Ton Tanks One of Biggest Headaches." New York Times. July 13, 1950.

Knox, Donald. The Korean War: An Oral History. San Diego, CA: Harcourt Brace Jovanovich, 1985.

Macartney, Roy. "YANKS FLEE 40 RED TANKS LEAVE WOUNDED ON FIELD: Survivors Describe 4 Hour Clash Near Osan." Chicago Daily Tribune. July 6, 1950. http://search.proquest.com/hnpchicagotribune/docview/177940406/abstract/2556E10939 D94596PQ/30.

Mellin, Ray. Task Force Smith: One Day of Combat and Three Years of Prison. Oral History, October 24, 2016. https://www.westpointcoh.org/interviews/task-force-smith-one-day-ofcombat-and-three-years-ofprison?fbclid=IwAR2GuWY7PiaR3ivCXFhKp6bYHAxC5LO6aKMbmHjyryy4SLUzJC AB4T6I33w.

"Numbers Will Win Present Korea Battle, Reporter Says, and Chinese Reds Have Them." The Washington Post (1923-1954); Washington, D.C. November 30, 1950. 
"Report of Special Committee on Organization of The Infantry Division." Fort Benning, GA:

The Infantry Conference, June 1946. Published by BiblioGov as part of "Infantry

Conference Report of Committee on Organization: June 1946, Part 3."

Ridgway, Matthew. The Korean War. Paperback. Garden City NY: Da Capo Press, 1986.

Simmons, Walter. "GIs FIGHT ON UNTIL AMMUNITION IS EXHAUSTED; ABANDON

BIG GUNS: Tribune Man Tells How Howitzers Shelled Foe.” Chicago Daily Tribune (1923-1963); Chicago, Ill. July 6, 1950, sec. Part 1.

Stickle, Sinclair. So They Will Know: A Korean War Memoir. Self-Published, 2013.

Tomedi, Rudy, ed. No Bugles, No Drums: An Oral History of the Korean War. New York, NY: John Wiley and Sons, 1993.

We Never Stop. The Big Picture. U.S. Army Signal Corps, 1952. https://www.youtube.com/watch?v=nu1 IdPpGipc\&list=PLqqqqZrD37h6YXQMqKLVng vya6CfiDb9X\&index $=41$.

\section{Secondary Sources:}

Appleman, Roy. South to The Naktong, North to The Yalu. Washington, D.C.: Center of Military History, U.S. Army, 1961.

Carruthers, Susan. The Good Occupation American Soldiers and the Hazards of Peace. Cambridge, MA: Harvard University Press, 2016.

Corum, James, and Wray Johnson. Airpower in Small Wars: Fighting Insurgents and Terrorists. Lawrence KA: University Press of Kansas, 2003.

Cumings, Bruce. The Korean War: A History. New York, NY: Modern Library, 2011.

Doubler, Michael. Closing With the Enemy: How GIs Fought the War in Europe. Lawrence KA: University Press of Kansas, 1994.

Fehrenbach, T.R. This Kind of War: The Classic Korean War History. Lincoln NE: Potomac Books, 2008.

Flynn, George. The Draft 1940-1973. Lawrence KS: University Press of Kansas, 1993.

Goncharov, Sergei, John Lewis, and Litai Xue. Uncertain Partners Stalin, Mao, and the Korean War. Stanford, CA: Stanford University Press, 1993.

Gugeler, Russell. Combat Actions in Korea. Army Historical Series. Washington, D.C.: Center of Military History, U.S. Army, 2000.

Hanson, Thomas. Combat Ready? The Eight U.S Army on the Eve of the Korean War. College Station TX: Texas A\&M University Press, 2010.

Heller, Charles, and William Stofft, eds. America's First Battles 1776-1965. Lawrence KA: University Press of Kansas, 1986.

Jaques, Christian. "United States Army Infantry Training Program Effectiveness During the Korean War.” U.S Army Command and General Staff College, 1995. https://apps.dtic.mil/sti/pdfs/ADA313127.pdf.

Kinkead, Eugene. In Every War But One. Westport, CT: Greenwood Press, 1959.

Knightley, Phillip. The First Casualty: The War Correspondent as Hero and Myth-Maker from the Crimea to Iraq. Third Edition. Baltimore: John Hopkins University Press, 2004.

Latham, William. Cold Days in Hell: American POWs in Korea. College Station TX: Texas A\&M University Press, 2012. 
Linn, Brian. Elvis's Army: Cold War GIs and the Atomic Battlefield. Cambridge, MA: Harvard University Press, 2016.

Longabaugh, Raymond M. "Task Force Smith and the 24th Infantry Division in Korea, July 1950.” ARMY COMMAND AND GENERAL STAFF COLLEGE FORT LEAVENWORTH KS SCHOOL OF ADVANCED MILITARY STUDIES, May 22, 2014. https://apps.dtic.mil/sti/citations/ADA612249.

Mansoor, Peter. The GI Offesnive in Europe: The Triumph of the American Infantry Divisions, 1941-1945. Lawrence KS: University Press of Kansas, 1999.

Marshall, S.L.A. Commentary on Infantry Operations and Weapons Usage in Korea: Winter of 1950-51. Edited by George Nafziger. West Chester, OH: The Nafziger Collection Inc., n.d.

- Men Against Fire: The Problem of Battle Command. Norman OK: University of Oklahoma Press, 2000.

- The River and the Gauntlet. Westport, CT: Greenwood Press, 1953.

Mossman, Billy. Ebb and Flow: November 1950-July 1951. Washington, D.C.: Center of Military History, U.S. Army, 1990.

Mundy, Lisa. American Militarism and Anti-Militarism in Popular Media 1945-1970. Jefferson NC: McFarland and Company Inc., 2012.

Neiberg, Michael. Making Citizen Soldiers: ROTC and the Ideology of American Military Service. Cambridge, MA: Harvard University Press, 2000.

Pash, Melinda. In the Shadow of the Greatest Generation. New York, NY: New York University Press, 2012.

Rutenberg, Amy. Rough Draft: Cold War Military Manpower Policy and the Origins of Vietnam-Era Draft Resistance. Ithaca: Cornell University Press, 2019.

Sandler, Stanley. The Korean War: No Victors, No Vanquished. Lexington KY: University Press of Kentucky, 1999.

Taylor, William. Military Service and American Democracy. Lawrence KA: University Press of Kansas, 2016. 